Atmos. Chem. Phys., 17, 11423-11440, 2017

https://doi.org/10.5194/acp-17-11423-2017

(c) Author(s) 2017. This work is distributed under

the Creative Commons Attribution 3.0 License.

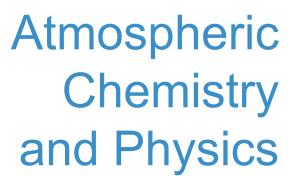

(c) (P)

\title{
Inflammatory responses to secondary organic aerosols (SOA) generated from biogenic and anthropogenic precursors
}

\author{
Wing Y. Tuet ${ }^{1}$, Yunle Chen ${ }^{2}$, Shierly Fok ${ }^{1}$, Julie A. Champion ${ }^{1}$, and Nga L. Ng ${ }^{1,3}$ \\ ${ }^{1}$ School of Chemical and Biomolecular Engineering, Georgia Institute of Technology, Atlanta, GA, USA \\ ${ }^{2}$ School of Materials Science and Engineering, Georgia Institute of Technology, Atlanta, GA, USA \\ ${ }^{3}$ School of Earth and Atmospheric Sciences, Georgia Institute of Technology, Atlanta, GA, USA \\ Correspondence to: Nga L. Ng(ng@chbe.gatech.edu)
}

Received: 20 March 2017 - Discussion started: 28 March 2017

Revised: 19 July 2017 - Accepted: 21 August 2017 - Published: 26 September 2017

\begin{abstract}
Cardiopulmonary health implications resulting from exposure to secondary organic aerosols (SOA), which comprise a significant fraction of ambient particulate matter (PM), have received increasing interest in recent years. In this study, alveolar macrophages were exposed to SOA generated from the photooxidation of biogenic and anthropogenic precursors (isoprene, $\alpha$-pinene, $\beta$-caryophyllene, pentadecane, $m$-xylene, and naphthalene) under different formation conditions $\left(\mathrm{RO}_{2}+\mathrm{HO}_{2}\right.$ vs. $\mathrm{RO}_{2}+\mathrm{NO}$ dominant, dry vs. humid). Various cellular responses were measured, including reactive oxygen and nitrogen species (ROS/RNS) production and secreted levels of cytokines, tumor necrosis factor- $\alpha$ (TNF- $\alpha$ ) and interleukin-6 (IL-6). SOA precursor identity and formation condition affected all measured responses in a hydrocarbon-specific manner. With the exception of naphthalene SOA, cellular responses followed a trend where TNF- $\alpha$ levels reached a plateau with increasing IL-6 levels. ROS/RNS levels were consistent with relative levels of TNF- $\alpha$ and IL-6, due to their respective inflammatory and anti-inflammatory effects. Exposure to naphthalene SOA, whose aromatic-ring-containing products may trigger different cellular pathways, induced higher levels of TNF- $\alpha$ and ROS/RNS than suggested by the trend. Distinct cellular response patterns were identified for hydrocarbons whose photooxidation products shared similar chemical functionalities and structures, which suggests that the chemical structure (carbon chain length and functionalities) of photooxidation products may be important for determining cellular effects. A positive nonlinear correlation was also detected between ROS/RNS levels and previously measured DTT (dithiothreitol) activities for SOA samples. In the context of ambient
\end{abstract}

samples collected during summer and winter in the greater Atlanta area, all laboratory-generated SOA produced similar or higher levels of ROS/RNS and DTT activities. These results suggest that the health effects of SOA are important considerations for understanding the health implications of ambient aerosols.

\section{Introduction}

Particulate matter (PM) exposure is a leading global risk factor for human health (Lim et al., 2012) with numerous studies reporting associations between elevated PM concentrations and increases in cardiopulmonary morbidity and mortality (Li et al., 2008; Pope III and Dockery, 2006; Brunekreef and Holgate, 2002; Dockery et al., 1993; Hoek et al., 2013; Anderson et al., 2011; Pope et al., 2002). A possible mechanism for PM-induced health effects has been suggested by toxicology studies, wherein PM-induced oxidant production, including reactive oxygen and nitrogen species (ROS/RNS), initiates inflammatory cascades, thus resulting in oxidative stress and cellular damage (Li et al., 2003a; Tao et al., 2003; Castro and Freeman, 2001; Gurgueira et al., 2002; Wiseman and Halliwell, 1996; Hensley et al., 2000). Furthermore, prolonged stimulation of these inflammatory cascades may lead to chronic inflammation, for which there is a recognized link to cancer (Philip et al., 2004). Together, these findings suggest that a possible relationship exists between PM exposure and observed health effects. 
Various assays have been developed to study PM-induced oxidant production, including cell-free chemical assays that measure the oxidative potential of PM samples (Kumagai et al., 2002; Cho et al., 2005; Fang et al., 2015b) as well as cellular assays that measure intracellular ROS/RNS produced as a result of PM exposure (Landreman et al., 2008; Tuet et al., 2016). Cell-free assays simulate biologically relevant redox (reduction-oxidation) reactions using an antioxidant species (e.g., dithiothreitol, DTT; ascorbic acid, AA). The antioxidant is oxidized via electron transfer reactions catalyzed by redox-active species in the PM sample, and its rate of decay serves as a measure of the concentration of redox-active species present (Fang et al., 2015b). On the other hand, cellular assays utilize a fluorescent probe (e.g., carboxy- $\mathrm{H}_{2}$ DCFDA) that reacts with ROS/RNS, and the measured fluorescence is proportional to the concentration of ROS/RNS produced as a result of PM exposure (Landreman et al., 2008; Tuet et al., 2016). Both types of assays have been utilized extensively to characterize a variety of PM samples and identify sources that may be detrimental to health (Verma et al., 2015a; Saffari et al., 2015; Fang et al., 2015a; Bates et al., 2015; Li et al., 2003b; Tuet et al., 2016). In particular, numerous studies suggest that organic carbon constituents, especially humic-like substances and oxygenated polyaromatic hydrocarbons, may contribute significantly to PM-induced oxidant production (Li et al., 2003b; Kleinman et al., 2005; Hamad et al., 2015; Verma et al., 2015b; Lin and Yu, 2011). Furthermore, recent measurements of ROS/RNS production and DTT activity using ambient samples collected in summer and winter around the greater Atlanta area showed that there is a significant correlation between summertime organic species and intracellular ROS/RNS production, suggesting a possible role for secondary organic aerosols (SOA; Tuet et al., 2016). The same study also reported a significant correlation between ROS/RNS production and DTT activity for summer samples, while a relatively flat ROS/RNS response was observed for winter samples spanning a similar DTT activity range (Tuet et al., 2016). These results highlight a need to consider multiple endpoints as a simple correlation may not exist between different endpoints, especially cellular responses that may result from complicated response networks.

Despite these findings, there are still many gaps in knowledge regarding PM-induced health effects. The current work will focus on the relative toxicities of different SOA systems, as field studies have repeatedly shown that SOA often dominate over primary aerosols (e.g., PM emitted directly from combustion engines) even in urban environments (Zhang et al., 2007; Jimenez et al., 2009; Ng et al., 2010). Furthermore, in recent years, there have been an increasing number of studies on the health effects of SOA formed from the oxidation of emitted hydrocarbons, demonstrating their potential contribution to PM-induced health effects (McWhinney et al., 2013; Rattanavaraha et al., 2011; Kramer et al., 2016; Lund et al., 2013; McDonald et al., 2010; McDonald et al., 2012;
Baltensperger et al., 2008; Arashiro et al., 2016; Platt et al., 2014; Gallimore et al., 2017). However, the cellular exposure studies involving SOA focused on SOA formed from a single precursor and included different measures of response (e.g., ROS/RNS, inflammatory biomarkers, gene expression; Arashiro et al., 2016; Lund et al., 2013; McDonald et al., 2010, 2012; Baltensperger et al., 2008; Lin et al., 2017). As a result, there is a lack of understanding in terms of the relative toxicity of individual SOA systems. Recently, Tuet et al. (2017) systematically investigated the DTT activities of SOA formed from different biogenic and anthropogenic precursors and demonstrated that intrinsic DTT activities were highly dependent on SOA precursor identity, with naphthalene SOA having the highest DTT activity. As a result, a systematic study on the cellular responses induced by these SOA systems may provide similar insights. Furthermore, cellular responses may complement these previously measured DTT activities to elucidate a more complete picture of the health effects of PM.

In the present study, murine alveolar macrophages were exposed to SOA generated under different formation conditions from various SOA precursors. Cellular responses induced by SOA exposure were measured, including intracellular ROS/RNS production and levels of tumor necrosis factor- $\alpha$ (TNF- $\alpha$ ) and interleukin-6 (IL-6). Intracellular ROS/RNS production serves as a general indicator of oxidative stress, whereas TNF- $\alpha$ and IL-6 are pro-inflammatory cytokines indicative of the inflammatory response (Henkler et al., 2010; Kishimoto, 2003; Wang et al., 2003). TNF- $\alpha$ is a hallmark biomarker involved in triggering a number of cellular signaling cascades. More specifically, TNF- $\alpha$ is involved in the activation of $\mathrm{NF}-\kappa \mathrm{B}$, which regulates the expression of a variety of genes involved in inflammation and cell death, and the activation of protein kinases, which regulate various signaling cascades (Witkamp and Monshouwer, 2000). IL-6 has both pro- and anti-inflammatory effects and may directly inhibit TNF- $\alpha$ (Kamimura et al., 2004). Furthermore, both cytokines are produced at relatively high levels in murine alveolar macrophages, ensuring a high signal-to-noise ratio and thus reliable measurements (Matsunaga et al., 2001; Chen et al., 2007). Precursors were chosen to include major classes of biogenic and anthropogenic compounds known to produce SOA upon atmospheric oxidation (Table S1 in the Supplement). The selected biogenic precursors include isoprene, the most abundant non-methane hydrocarbon (Guenther et al., 2006); $\alpha$-pinene, a well-studied monoterpene with emissions on the order of global anthropogenic emissions (Guenther et al., 1993; Piccot et al., 1992); and $\beta$ caryophyllene, a representative sesquiterpene. Both monoterpenes and sesquiterpenes have been shown to contribute significantly to ambient aerosol (Eddingsaas et al., 2012; Hoffmann et al., 1997; Tasoglou and Pandis, 2015; Goldstein and Galbally, 2007). Similarly, the anthropogenic precursors include pentadecane, a long-chain alkane; $m$-xylene, a singlering aromatic; and naphthalene, a polyaromatic. These com- 
pounds are emitted as products of incomplete combustion (Robinson et al., 2007; Jia and Batterman, 2010; Bruns et al., 2016) and have considerable SOA yields (Chan et al., 2009; $\mathrm{Ng}$ et al., 2007b; Lambe et al., 2011). In addition to precursor identity, the effects of humidity (dry vs. humid) and $\mathrm{NO}_{x}$ levels (different predominant peroxy radical, $\mathrm{RO}_{2}$, fates; $\mathrm{RO}_{2}+\mathrm{HO}_{2}$ vs. $\mathrm{RO}_{2}+\mathrm{NO}$ ) on $\mathrm{SOA}$ cellular inflammatory responses were investigated, as different formation conditions have been shown to affect aerosol chemical composition and mass loading, which could in turn result in a different cellular response (Chhabra et al., 2010, 2011; Eddingsaas et al., 2012; Ng et al., 2007a, b; Loza et al., 2014; Chan et al., 2009; Boyd et al., 2015). Finally, correlations between bulk aerosol composition, specifically elemental ratios, and cellular inflammatory responses were investigated to determine whether there is a link between different inflammatory responses and aerosol composition.

\section{Methods}

\subsection{Alveolar macrophage cell line}

Exposures were conducted using immortalized murine alveolar macrophages (MH-S, ATCC ${ }^{\circledR}$ CRL-2019 ${ }^{\mathrm{TM}}$ ) as they are the first line of defense against environmental insults (Oberdörster, 1993; Oberdörster et al., 1992). The particular cell line also retains many properties of primary alveolar macrophages, including phagocytosis as well as the production of ROS/RNS and cytokines (Sankaran and Herscowitz, 1995; Mbawuike and Herscowitz, 1989). MH-S cells were cultured in RPMI-1640 media supplemented with $10 \%$ fetal bovine serum (FBS, Quality Biological, Inc.), $1 \%$ penicillin-streptomycin, and $50 \mu \mathrm{M} \beta$ mercaptoethanol (BME) at $37^{\circ} \mathrm{C}$ and humid air containing $5 \% \mathrm{CO}_{2}$. For exposure experiments, $\mathrm{MH}-\mathrm{S}$ cells were seeded at a density of $2 \times 10^{4}$ cells well $^{-1}$ onto 96 -well plates pretreated with $10 \%$ FBS in phosphate-buffered saline (PBS, Cellgro). For seeding and all assay procedures thereon, FBSsupplemented cell culture media without BME addition was used as BME is a reducing agent that may interfere with inflammatory measurements.

\subsection{Chamber experiments}

SOA formed from the photooxidation of biogenic and anthropogenic precursors were generated in the Georgia Tech Environmental Chamber (GTEC) facility. Details of the facility have been described elsewhere (Boyd et al., 2015). Briefly, the chamber facility consists of two $12 \mathrm{~m}^{3}$ Teflon chambers suspended within a $6.4 \mathrm{~m} \times 3.7 \mathrm{~m}(21 \mathrm{ft} \times 12 \mathrm{ft})$ temperature-controlled enclosure. Black lights and natural sunlight fluorescent lamps surround the chambers, and multiple sampling ports allow for injection of reagents as well as gas- and aerosol-phase measurements. Gas-phase $\mathrm{O}_{3}, \mathrm{NO}_{2}$, and $\mathrm{NO}_{x}$ concentrations were monitored using an $\mathrm{O}_{3}$ ana-
Table 1. Experimental conditions.

\begin{tabular}{llllr}
\hline Experiment & $\begin{array}{l}\text { SOA } \\
\text { precursor }\end{array}$ & $\begin{array}{l}\mathrm{OH} \\
\text { precursor }\end{array}$ & $\begin{array}{l}\text { Relative } \\
\text { humidity } \\
(\%)\end{array}$ & $\begin{array}{r}{[\mathrm{HC}]_{0}} \\
(\mathrm{ppb})\end{array}$ \\
\hline 1 & isoprene & $\mathrm{H}_{2} \mathrm{O}_{2}$ & $<5 \%$ & 97 \\
2 & $\alpha$-pinene & $\mathrm{H}_{2} \mathrm{O}_{2}$ & $<5 \%$ & 191 \\
3 & $\beta$-caryophyllene & $\mathrm{H}_{2} \mathrm{O}_{2}$ & $<5 \%$ & 36 \\
4 & pentadecane & $\mathrm{H}_{2} \mathrm{O}_{2}$ & $<5 \%$ & 106 \\
5 & $m$-xylene & $\mathrm{H}_{2} \mathrm{O}_{2}$ & $<5 \%$ & 450 \\
6 & naphthalene & $\mathrm{H}_{2} \mathrm{O}_{2}$ & $<5 \%$ & 178 \\
7 & isoprene & $\mathrm{H}_{2} \mathrm{O}_{2}$ & $<5 \% *$ & 97 \\
8 & $\alpha$-pinene & $\mathrm{H}_{2} \mathrm{O}_{2}$ & $40 \%$ & 334 \\
9 & $\beta$-caryophyllene & $\mathrm{H}_{2} \mathrm{O}_{2}$ & $42 \%$ & 63 \\
10 & pentadecane & $\mathrm{H}_{2} \mathrm{O}_{2}$ & $45 \%$ & 106 \\
11 & $m$-xylene & $\mathrm{H}_{2} \mathrm{O}_{2}$ & $45 \%$ & 450 \\
12 & naphthalene & $\mathrm{H}_{2} \mathrm{O}_{2}$ & $44 \%$ & 431 \\
13 & isoprene & $\mathrm{HONO}^{2}$ & $<5 \%$ & 970 \\
14 & $\alpha$-pinene & $\mathrm{HONO}^{2}$ & $<5 \%$ & 174 \\
15 & $\beta$-caryophyllene & $\mathrm{HONO}^{2}$ & $<5 \%$ & 21 \\
16 & pentadecane & $\mathrm{HONO}$ & $<5 \%$ & 74 \\
17 & $m$-xylene & $\mathrm{HONO}$ & $<5 \%$ & 431 \\
18 & naphthalene & $\mathrm{HONO}$ & $<5 \%$ & 145 \\
\hline
\end{tabular}

Acidic seed $\left(8 \mathrm{mM} \mathrm{MgSO}_{4}\right.$ and $\left.16 \mathrm{mMH}_{2} \mathrm{SO}_{4}\right)$ was used instead of $8 \mathrm{mM}\left(\mathrm{NH}_{4}\right)_{2} \mathrm{SO}_{4}$.

lyzer (Teledyne T400), a cavity attenuated phase shift $\mathrm{NO}_{2}$ monitor (Aerodyne), and a chemiluminescence $\mathrm{NO}_{x}$ monitor (Teledyne 200EU), respectively, while hydrocarbon decay was monitored using a gas chromatography-flame ionization detector (Agilent 7890A). Hydrocarbon decay was also used to estimate hydroxyl radical $(\mathrm{OH})$ concentrations. For aerosol-phase measurements, a scanning mobility particle sizer (SMPS, TSI) was used to measure aerosol volume concentrations and distributions, while a High-Resolution Timeof-Flight Aerosol Mass Spectrometer (HR-ToF-AMS, Aerodyne; henceforth referred to as the AMS) was used to determine bulk aerosol composition (DeCarlo et al., 2006). AMS data was analyzed using the data analysis toolkit SQUIRREL (v. 1.57) and PIKA (v. 1.16G). Elemental ratios, including $\mathrm{O}: \mathrm{C}, \mathrm{H}: \mathrm{C}$, and $\mathrm{N}: \mathrm{C}$, were obtained using the method outlined by Canagaratna et al. (2015) and used to calculate the average carbon oxidation state $\left(\overline{\mathrm{OS}}_{\mathrm{c}} ;\right.$ Kroll et al., 2011). Temperature and relative humidity (RH) were also monitored using a hydro-thermometer (Vaisala HMP110).

Experiments were designed to probe the effects of humidity, $\mathrm{RO}_{2}$ fate, and precursor identity on cellular inflammatory responses induced by different SOA formed under these conditions (Table 1). All chamber experiments were performed at $\sim 25^{\circ} \mathrm{C}$ under dry $(\mathrm{RH}<5 \%)$ or humid $(\mathrm{RH} \sim 45 \%)$ conditions. Chambers were flushed with pure air (generated from AADCO 747-14) for $\sim 24 \mathrm{~h}$ prior to each experiment. During this time, chambers were also humidified for humid experiments by means of a bubbler filled with deionized water. Seed aerosol was injected by atomizing a $15 \mathrm{mM}\left(\mathrm{NH}_{4}\right)_{2} \mathrm{SO}_{4}$ seed solution (Sigma Aldrich) to obtain a seed concentration of $\sim 20 \mu \mathrm{g} \mathrm{m}^{-3}$. It should be noted that experimen- 
tal conditions deviate for experiment 7 (isoprene SOA under $\mathrm{RO}_{2}+\mathrm{HO}_{2}$ dominant, "humid" conditions) due to low SOA mass yields. For this experiment, an acidic seed solution $\left(8 \mathrm{mMMgSO}_{4}\right.$ and $\left.16 \mathrm{mM} \mathrm{H}_{2} \mathrm{SO}_{4}\right)$ and a dry chamber were used to promote SOA formation via the isoprene epoxydiol (IEPOX) uptake pathway. This pathway has been shown to contribute significantly to ambient $\mathrm{OA}$ and has a higher SOA mass yield compared to the IEPOX $+\mathrm{OH}$ pathway (Surratt et al., 2010; Lin et al., 2012; Xu et al., 2015).

SOA precursor was then introduced by injecting a known amount of hydrocarbon solution (isoprene, $99 \% ; \alpha$-pinene, $\geq 99 \% ; \beta$-caryophyllene, $>98.5 \%$; pentadecane, $\geq 99 \%$; $m$-xylene, $\geq 99 \%$; naphthalene, $99 \%$; Sigma Aldrich) into a glass injection bulb and passing pure air over the solution until it fully evaporated. For pentadecane and $\beta$-caryophyllene, the glass bulb was also heated gently during hydrocarbon injection to ensure full evaporation (Tasoglou and Pandis, 2015). Naphthalene was injected by passing pure air over solid naphthalene flakes as described in previous studies (Chan et al., 2009). OH precursor was then introduced via injection of hydrogen peroxide $\left(\mathrm{H}_{2} \mathrm{O}_{2}\right)$ for $\mathrm{RO}_{2}+\mathrm{HO}_{2}$ experiments or nitrous acid (HONO) for $\mathrm{RO}_{2}+\mathrm{NO}$ experiments. For $\mathrm{H}_{2} \mathrm{O}_{2}$, a $50 \%$ aqueous solution (Sigma Aldrich) was injected using the same method described for hydrocarbon injection to achieve an $\mathrm{H}_{2} \mathrm{O}_{2}$ concentration of $3 \mathrm{ppm}$. This amount yielded $\mathrm{OH}$ concentrations on the order of $10^{6} \mathrm{molec} \mathrm{cm}^{-3}$. For HONO injections, HONO was first prepared by adding $10 \mathrm{~mL}$ of $1 \%$ wt aqueous $\mathrm{NaNO}_{2}$ (VWR International) dropwise into $20 \mathrm{~mL}$ of $10 \% \mathrm{wt} \mathrm{H}_{2} \mathrm{SO}_{4}$ (VWR International) in a glass bulb. Zero air was then passed over the solution to introduce HONO into the chamber (Chan et al., 2009; Kroll et al., 2005). Photolysis of HONO yielded $\mathrm{OH}$ concentrations on the order of $10^{7}$ molec $\mathrm{cm}^{-3}$. NO and $\mathrm{NO}_{2}$ were also formed as byproducts of HONO synthesis. Once all the $\mathrm{H}_{2} \mathrm{O}_{2}$ evaporated $\left(\mathrm{RO}_{2}+\mathrm{HO}_{2}\right.$ experiments) or $\mathrm{NO}_{x}$ concentrations stabilized $\left(\mathrm{RO}_{2}+\mathrm{NO}\right.$ experiments), the UV lights were turned on to initiate photooxidation.

\subsection{Aerosol collection and extraction}

Aerosol samples were collected onto $47 \mathrm{~mm}^{\text {Teflon }}{ }^{\mathrm{TM}}$ filters ( $0.45 \mu \mathrm{m}$ pore size, Pall Laboratory). The total mass collected onto each filter was determined by integrating the SMPS time-dependent volume concentration over the filter collection period and multiplying by the total volume of air collected. SMPS volume concentrations were converted to mass concentrations by assuming a density of $1 \mathrm{~g} \mathrm{~cm}^{-3}$ to facilitate comparison between studies. To account for potential $\mathrm{H}_{2} \mathrm{O}_{2}$ or HONO uptake, background filters were also collected. These filters were collected when only seed particles and $\mathrm{OH}$ precursor $\left(\mathrm{H}_{2} \mathrm{O}_{2}\right.$ or $\left.\mathrm{HONO}\right)$ were injected into the chamber under otherwise identical experimental conditions. All collected samples were placed in sterile petri dishes, sealed with Parafilm $\mathrm{M}^{\circledR}$, and stored at $-20^{\circ} \mathrm{C}$ until extraction and analysis (Fang et al., 2015b). Collected particles were extracted following the procedure outlined in Fang et al. (2015a) with modifications for cellular exposure. Briefly, filter samples were submerged in cell culture media (RPMI-1640) and sonicated for two $30 \mathrm{~min}$ intervals (1 $\mathrm{h}$ total) using an ultrasonic cleanser (VWR International). In between sonication intervals, the water was replaced to reduce bath temperature. After the final sonication interval, sample extracts were filtered using $0.45 \mu \mathrm{m}$ PTFE syringe filters (Fisherbrand ${ }^{\mathrm{TM}}$ ) to remove any insoluble material and supplemented with $10 \%$ FBS (Fang et al., 2015b).

\subsection{Intracellular ROS/RNS measurement}

ROS/RNS were detected using the assay optimized in Tuet et al. (2016). Briefly, the assay consists of five major steps: (1) pretreatment of 96-well plates to ensure a uniform cell density, (2) seeding of cells onto pretreated wells at $2 \times 10^{4}$ cells well $^{-1}$, (3) incubation with ROS/RNS probe (carboxy- $\mathrm{H}_{2}$ DCFDA, Molecular Probes C-400) diluted to a final concentration of $10 \mu \mathrm{M}$, (4) exposure of probetreated cells to samples and controls for $24 \mathrm{~h}$, and (5) detection of ROS/RNS using a microplate reader (BioTek Synergy H4, excitation/emission: 485/525 nm). Positive controls included bacterial cell wall component lipopolysaccharide (LPS, $\left.1 \mu \mathrm{g} \mathrm{mL}^{-1}\right), \mathrm{H}_{2} \mathrm{O}_{2}(100 \mu \mathrm{M})$, and reference filter extract (10 filter punches $\mathrm{mL}^{-1}, 1$ per filter sample, from various ambient filters collected at the Georgia Tech site), while negative controls included blank filter extract ( 2 punches $\mathrm{mL}^{-1}$ ) and control cells (probe-treated cells exposed to media only, no stimulants).

A previous study on the ROS/RNS induced by exposure to ambient PM samples found that ROS/RNS production was highly dose dependent and could therefore not be represented by measurements taken at a single dose (Tuet et al., 2016). Here, we utilize the dose-response curve approach described in Tuet et al. (2016). For each aerosol sample, ROS/RNS production was measured over 10 dilutions and expressed as a fold increase in fluorescence over control cells. A representative dose-response curve is shown in Fig. 1. For comparisons to other inflammatory endpoints and chemical composition, ROS/RNS production was represented using the area under the dose-response curve (AUC), as AUC has been shown to be the most robust metric for comparing PM samples (Tuet et al., 2016).

\subsection{Cytokine measurement}

Secreted levels of TNF- $\alpha$ and IL- 6 were measured postexposure $(24 \mathrm{~h})$ using enzyme-linked immunosorbent assay (ELISA) kits following the manufacturer's specifications (ThermoFisher). This time point was chosen to enable comparison with ROS/RNS levels (also measured at $24 \mathrm{~h}$, optimized in Tuet et al., 2016) and to ensure a high signal for both cytokines. Previous literature has shown that TNF- $\alpha$ and IL-6 production peak around 4 and $24 \mathrm{~h}$, respectively (Had- 


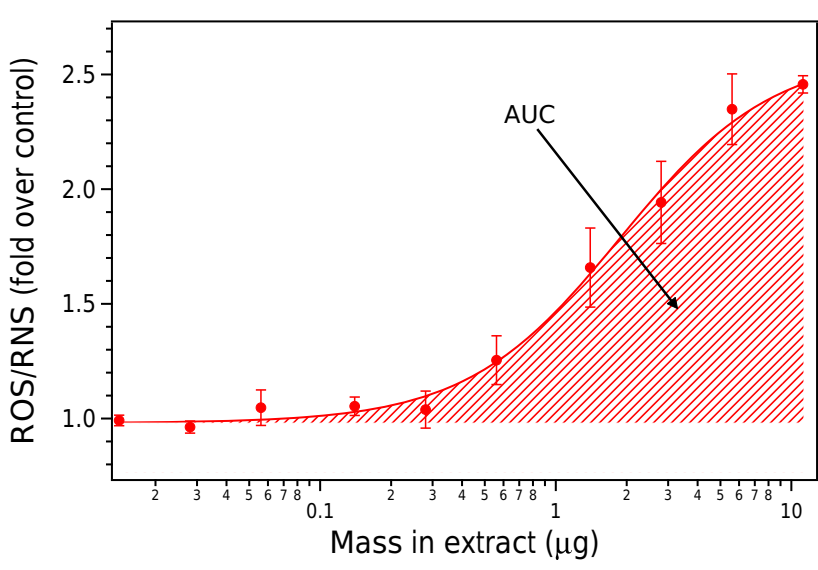

Figure 1. Representative dose-response curve of ROS/RNS produced as a result of filter exposure (naphthalane SOA formed under dry, $\mathrm{RO}_{2}+\mathrm{NO}$ dominant conditions). ROS/RNS is expressed as a fold increase over control cells, defined as probe-treated cells incubated with stimulant-free media. Dose is expressed as mass in extract $(\mu \mathrm{g})$. Data shown are means \pm standard error of triplicate exposure experiments. The Hill equation was used to fit the doseresponse curve and the area under the dose-response curve (AUC) is shown.

dad, 2001). However, while TNF- $\alpha$ production peaks earlier, the signal at $24 \mathrm{~h}$ is well above the detection limit of the assay, and previous studies have utilized this time point to measure both cytokines (Haddad, 2001; Matsunaga et al., 2001). Nonetheless, it should be noted that these measurements represent a single time point in the cellular response. All measurements were carried out using undiluted cell culture supernatant. For each aerosol sample, TNF- $\alpha$ and IL-6 were measured over seven dilutions and represented as a fold increase over control. Similarly, the AUC was used to represent each endpoint for comparison purposes.

\subsection{Cellular metabolic activity}

The MTT (3-(4,5-dimethylthiazol-2-yl)-2,5diphenyltetrazolium bromide) assay (Biotium) was used to assess cellular metabolic activity. Briefly, supernatants containing sample extracts were removed after the exposure period and replaced with media containing MTT. Cells were then returned to the incubator for $4 \mathrm{~h}$, during which the tetrazolium dye was reduced by cellular $\mathrm{NAD}(\mathrm{P}) \mathrm{H}$-dependent oxidoreductases to produce an insoluble purple salt (formazan). Dimethyl sulfoxide was then used to solubilize the salt, and the absorbance at $570 \mathrm{~nm}$ was determined using a microplate reader (BioTek Synergy H4).

\subsection{Statistical analysis}

Linear regressions between bulk aerosol composition and cellular inflammatory responses were evaluated using Pearson's correlation coefficient, and the significance of each cor-

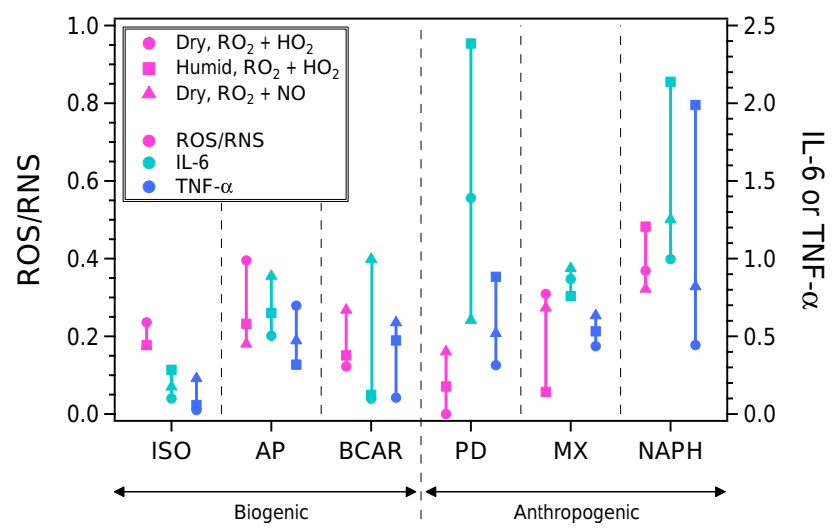

Figure 2. Area under the dose-response curve for various inflammatory responses induced as a result of SOA exposure: ROS/RNS, IL6 , and TNF- $\alpha$. SOA were generated from various precursors (ISO: isoprene, AP: $\alpha$-pinene, BCAR: $\beta$-caryophyllene, PD: pentadecane, MX: $m$-xylene, and NAPH: naphthalene) under various conditions (circles: dry, $\mathrm{RO}_{2}+\mathrm{HO}_{2}$; squares: humid, $\mathrm{RO}_{2}+\mathrm{HO}_{2}$; and triangles: dry, $\mathrm{RO}_{2}+\mathrm{NO}$ ). Lines connecting the same inflammatory response for SOA generated from the same precursor under different formation conditions are also shown.

relation coefficient was determined using multiple imputation, which calculated the total variance associated with the slope of each regression. Details of this method are described in Pan and Shimizu (2009). Briefly, response parameters (i.e., AUCs for each endpoint) were assumed to follow a normal distribution. Ten "estimates" were obtained for each response using the average and standard deviation determined from the dose-response curve fit. These estimates were then plotted against bulk aerosol composition (e.g., O : C, H:C, and $\mathrm{N}: \mathrm{C}$ ) to obtain 10 fits, and the slopes and variances generated from these fits were used to calculate the between and within variance. Finally, a Student's $t$ test was used to calculate and evaluate the associated $p$ values using a $95 \%$ confidence interval.

\section{Results and discussion}

\subsection{Effect of SOA precursor and formation condition on SOA inflammatory response}

To investigate whether SOA formed from different precursors elicited different inflammatory responses, levels of ROS/RNS, TNF- $\alpha$, and IL- 6 were measured after exposing alveolar macrophages to SOA generated from six volatile organic compounds generated under three formation conditions (Table 1). The AUC per mass of SOA $(\mu \mathrm{g})$ in the extract for ROS/RNS, TNF- $\alpha$, and IL-6 are shown in Fig. 2, shaped by SOA formation condition. It should be noted that all responses were normalized to probe-treated control cells to account for differences between endogenous levels of ROS/RNS produced in cells (Henkler et al., 2010). Un- 
certainties associated with AUC were determined by averaging the AUCs obtained by fitting dose-response data with each point removed systematically, following the methodology described in Tuet et al. (2016). ROS/RNS production was also measured for background filters and found to be within the uncertainty of control cells, indicating that there was no evidence for significant $\mathrm{H}_{2} \mathrm{O}_{2}$ or $\mathrm{HONO}$ uptake onto seed particles (Fig. S1 in the Supplement). Furthermore, exposure to filter extract did not result in decreases in metabolic activity as measured by the MTT assay for all SOA systems investigated (Fig. S2). Since results from MTT may represent the number of viable cells present, changes in inflammatory endpoints did not likely result from changes in the number of cells exposed (i.e., decreases in response cannot be attributed to cell death).

For all inflammatory responses measured (levels of ROS/RNS, TNF- $\alpha$, and IL-6), SOA precursor identity and formation condition influenced the level of response, as demonstrated by the range of values obtained from different SOA precursors and different formation conditions (Fig. 2). Despite having a clear effect, no obvious trends were observed for each variable (precursor or formation condition) on individual responses. This is in contrast to that observed for the oxidative potential as measured by DTT (OPWS-DTT) for these samples, where only precursor identity influenced OPWS-DTT substantially (Tuet et al., 2017). However, this may not be surprising as DTT is a chemical assay, which only accounts for the potential of species to participate in redox reactions (Cho et al., 2005), whereas cellular assays account for many complicated cellular events involved in intricate positive and negative feedback loops. Due to the considerably different classes of compounds chosen as SOA precursors, aerosol compositional changes between different precursors were generally larger than those between different formation conditions of the same precursor (see Fig. 3a; Tuet et al., 2017). DTT may only be sensitive to larger differences arising from different precursors, whereas cellular assays could also be sensitive to differences between different formation conditions and chemical composition of the same precursor. Moreover, while Tuet et al. (2017) showed that the intrinsic OPWS-DTT spanned a wide range, with isoprene and naphthalene SOA generating the lowest and highest OP ${ }^{\mathrm{WS}-\mathrm{DTT}}$, these bounds were less clear for cellular responses. While isoprene and naphthalene SOA still generated the lowest and highest inflammatory responses in general, a few exceptions exist (e.g., ROS/RNS levels induced by pentadecane SOA formed under dry, $\mathrm{RO}_{2}+\mathrm{HO}_{2}$ dominant conditions, Fig. 2).

Though no apparent trends in individual inflammatory responses were observed as a function of SOA precursor identity or formation condition, several patterns among all three inflammatory responses were observed for SOA precursors whose products share similar chemical structures (i.e., similar carbon chain length and functionalities). Exposure to isoprene SOA induced the lowest levels of TNF- $\alpha$ and IL6 among the aerosol systems studied (Fig. 2). Furthermore,
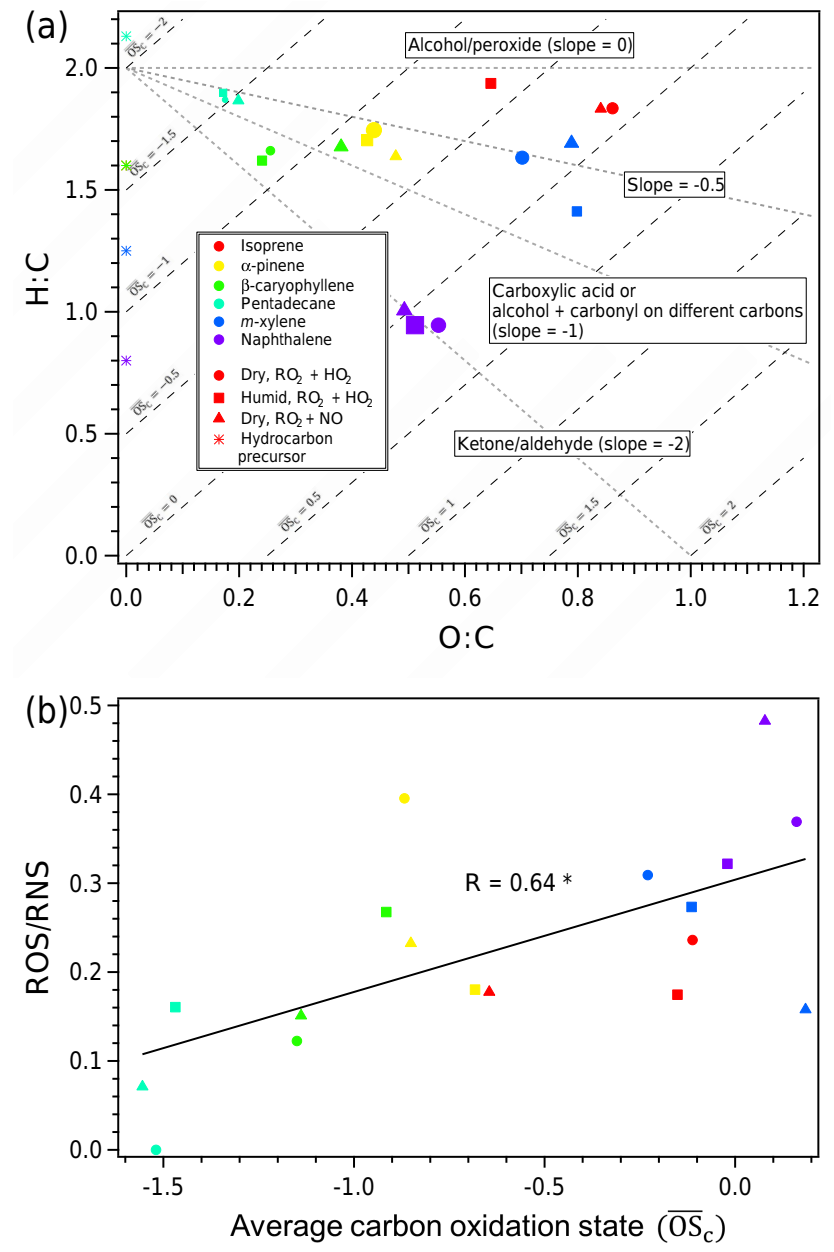

Figure 3. Van Krevelen plot for various SOA systems sized by ROS/RNS levels (a) and correlation between ROS/RNS levels and average carbon oxidation state (b). Data points are colored by the SOA system (red: isoprene, yellow: $\alpha$-pinene, green: $\beta$ caryophyllene, light blue: pentadecane, blue: $m$-xylene, and purple: naphthalene), shaped according to formation conditions (circle: dry, $\mathrm{RO}_{2}+\mathrm{HO}_{2}$; square: humid, $\mathrm{RO}_{2}+\mathrm{HO}_{2}$; and triangle: dry, $\mathrm{RO}_{2}+\mathrm{NO}$ ). SOA precursors are shown as stars, colored by the SOA system. ${ }^{*}$ indicates significance, $p<0.05$.

isoprene SOA generated from different pathways (i.e., photooxidation under different $\mathrm{RO}_{2}$ fates and reactive uptake of IEPOX; Surratt et al., 2010; Xu et al., 2014; Chan et al., 2010) produced similar responses for each inflammatory endpoint. These results suggest that different isoprene SOA products (Surratt et al., 2010; Xu et al., 2014; Chan et al., 2010) may induce similarly low inflammatory responses and are consistent with the intrinsic OPWS-DTT obtained for these SOA samples, where isoprene SOA generated the lowest OPWS-DTT of all SOA systems studied and the OPWS-DTT was similar for all SOA formation conditions explored (Tuet et al., 2017). This finding is in contrast to a previous study by Lin et al. (2016), where methacrylic acid epoxide (MAE)- 
derived SOA was found to be substantially more potent than IEPOX-derived SOA. However, while exposure to MAEderived SOA induced the upregulation of a larger number of oxidative stress response genes than IEPOX-derived SOA, the fold changes of several genes reported in Lin et al. (2016) are actually similar (e.g., ALOX12, NQO1). Several of these genes directly affect the production of inflammatory cytokines measured in this study. For instance, studies have observed that arachidonate 12-lipoxygenase (ALOX12) products induce the production of both TNF- $\alpha$ and IL-6 in macrophages (Wen et al., 2007). As such, a similar response level regardless of SOA formation condition may be observed depending on the biological endpoints measured. Thus, it is possible that the inflammatory cytokines measured in this study are involved in pathways concerning those genes, resulting in a similar response level regardless of SOA formation condition.

Similarly, exposure to SOA generated from the photooxidation of $\alpha$-pinene and $m$-xylene resulted in similar inflammatory responses for all three formation conditions (Fig. 2). These cellular assay results are consistent with results from

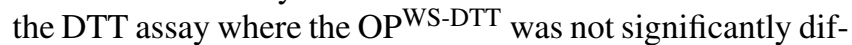
ferent between SOA formed under different formation conditions (Tuet et al., 2017). Response levels induced by these two SOA systems are also similar across all three inflammatory measurements investigated (Fig. 2). This suggests that products from both precursors may induce similar cellular pathways resulting in the production of similar levels of inflammatory markers. Indeed, there are several similarities between products formed from the photooxidation of $\alpha$-pinene and $m$-xylene. For instance, a large portion of $\alpha$-pinene and $m$-xylene oxidation products under both $\mathrm{RO}_{2}+\mathrm{HO}_{2}$ and $\mathrm{RO}_{2}+\mathrm{NO}$ pathways are ring-breaking products with a similar carbon chain length (Eddingsaas et al., 2012; Vivanco and Santiago, 2010; Jenkin et al., 2003). As a result of this similarity, products from both SOA systems may interact with the same cellular targets and induce similar cellular pathways, resulting in a similar response regardless of precursor identity and formation condition. These observations further imply that the chemical structures (e.g., carbon chain lengths and functionalities) of oxidation products may be important regardless of PM source or precursor.

A different pattern was observed for $\beta$-caryophyllene and pentadecane SOA, where the IL-6 response spanned a much larger range than $\mathrm{ROS} / \mathrm{RNS}$ and $\mathrm{TNF}-\alpha$ (Fig. 2). This is in contrast to the trends observed for the OPWS-DTT for $\beta$ caryophyllene and pentadecane SOA, where OPWS-DTT was similar regardless of formation condition (Tuet et al., 2017). This suggests that there are differences between organic peroxides and organic nitrates formed from certain precursors that influence cellular responses, but they are not captured by redox potential measurements. Less is known about the effects of humidity on SOA formation and chemical composition for all SOA systems investigated, as most laboratory chamber studies in literature have been conducted under dry conditions. Specifically here, very high levels of IL-6 were observed post-exposure to pentadecane SOA formed under humid conditions. Prior studies reported opposing findings with some showing a significant effect of water on aerosol formation and chemical composition (Nguyen et al., 2011; Wong et al., 2015; Healy et al., 2009; Stirnweis et al., 2016), while others found little influence (Edney et al., 2000; Boyd et al., 2015; Cocker III et al., 2001). It is clear that humidity effects are highly hydrocarbon-dependent and further studies into the specific products formed under humid conditions are required to understand how these differences in chemical composition may translate to different cellular endpoints. Nonetheless, the known products formed from the photooxidation of these hydrocarbons may provide some insight into the inflammatory responses observed. While there are no prior studies involving pentadecane oxidation products, it is expected that the oxidation products will be similar to those reported in the oxidation of dodecane (i.e., same functionalities with a longer carbon chain; Loza et al., 2014). It is therefore likely that pentadecane oxidation products resemble long chain fatty acids and could potentially insert into the cell membrane (Loza et al., 2014), as previous studies have shown that fatty acids can feasibly insert into the cell membrane bilayer (Khmelinskaia et al., 2014; Cerezo et al., 2011). This insertion could potentially affect membrane fluidity, which is known to affect cell function substantially although the specific effect depends strongly on the particular modification and cell type of interest (Baritaki et al., 2007; Spector and Yorek, 1985). In some cases, these alterations lead to the induction of apoptosis, which involves pathways leading to the production of TNF- $\alpha$ (Baritaki et al., 2007; Wang et al., 2003). TNF- $\alpha$ can then induce the production of IL-6, which once produced can also inhibit the production of TNF$\alpha$ in a feedback loop (Kishimoto, 2003; Wang et al., 2003). These cellular events are consistent with the observed inflammatory response induced by pentadecane SOA exposure, where there is a high IL-6 response and a lower TNF- $\alpha$ response. The low ROS/RNS response observed is also in line with these cellular events, as IL-6 exhibits anti-inflammatory functions, which can neutralize ROS/RNS production. These responses are less pronounced for $\beta$-caryophyllene aerosol, which may be due to the shorter carbon chain observed in known products (Chan et al., 2011). While $\beta$-caryophyllene and pentadecane are both $\mathrm{C} 15$ precursors, $\beta$-caryophyllene is a bicyclic compound and many SOA products retain the fourmembered ring, resulting in a shorter carbon backbone (Chan et al., 2011). As a result, fewer products may insert into the cell membrane, leading to a lower response compared to pentadecane SOA exposure. These observations, particularly those for pentadecane SOA, suggest that aerosols from meat cooking may have health implications, as fatty acids comprise a majority of these aerosols (Mohr et al., 2009; Rogge et al., 1991).

Naphthalene exhibits a different, more distinct pattern compared to the rest of the SOA systems investigated, with a 
large range observed for both TNF- $\alpha$ and IL- 6 under different formation conditions (Fig. 2). Higher levels of ROS/RNS were also observed as a result of exposure to naphthalene aerosol irrespective of SOA formation condition. Similarly, the OPWS-DTT of naphthalene SOA previously measured by Tuet et al. (2017) was an outlier among all SOA systems investigated, as the measured OPWS-DTT was at least twice that of the next highest SOA system. These observations are consistent with the formation of specific SOA products such as naphthoquinones, which are known to induce redox cycling in cells and are formed under both $\mathrm{RO}_{2}+\mathrm{HO}_{2}$ and $\mathrm{RO}_{2}+\mathrm{NO}$ pathways (Henkler et al., 2010; Kautzman et al., 2010). Consequently, aerosol generated from naphthalene may induce higher levels of inflammatory responses than other SOA due to this process (Henkler et al., 2010; Lorentzen et al., 1979). However, as shown by the high levels of IL-6, exposure to naphthalene SOA may also induce anti-inflammatory pathways not captured by OPWS-DTT measurements. Moreover, a clear increasing trend is apparent for TNF- $\alpha$ and IL-6 produced upon naphthalene SOA exposure, with a higher level of both cytokines observed for aerosol formed under $\mathrm{RO}_{2}+\mathrm{NO}$ dominant and humid conditions. Previously, the effect of different $\mathrm{RO}_{2}$ fates on SOA OPWS-DTT was attributed to the different products known to form under both pathways (Tuet et al., 2017). The same explanation applies for cellular measurements as SOA products that promote electron transfer reactions with antioxidants can result in a redox imbalance as measured by OPWS-DTT and the induction of related cellular pathways such as ROS/RNS and cytokine production (Tuet et al., 2017). Finally, naphthalene SOA induced cellular responses outside of those observed for other aerosol systems, with higher levels of all inflammatory markers than other SOA systems. As shown previously for OPWS-DTT, naphthalene may be an outlier due to aromatic-ring-containing products, which may then induce different cellular pathways compared to other aerosol systems investigated, the products of which do not contain aromatic rings. Additionally, many known aerosol products formed from the photooxidation of naphthalene have functionalities that resemble those of dinitrophenol, which is known to decouple phosphorylation from electron transfer (Terada, 1990). It is therefore possible that the aromatic functionality present in the majority of naphthalene SOA products results in the involvement of very different cellular pathways, leading to outlier inflammatory endpoint responses. Various products of naphthalene oxidation such as nitroaromatics and polyaromatics are known to have mutagenic properties and may induce the formation of DNA adducts (Baird et al., 2005; Helmig et al., 1992). As such, it is possible that these products may induce health effects via other pathways as well and naphthalene SOA exposure may have effects beyond redox imbalance and oxidative stress.

Bulk aerosol elemental ratios $(\mathrm{O}: \mathrm{C}, \mathrm{H}: \mathrm{C}$, and $\mathrm{N}: \mathrm{C})$ were determined for each SOA system investigated. Different types of organic aerosol are known to span a wide range of $\mathrm{O}: \mathrm{C}$ ratios, which may be utilized as an indication of oxidation, and the van Krevelen diagram was used to visualize whether changes in $\mathrm{O}: \mathrm{C}$ and $\mathrm{H}: \mathrm{C}$ ratios corresponded to changes in levels of inflammatory response (Figs. 3a and S3; Chhabra et al., 2011; Lambe et al., 2011; Ng et al., 2010). Changes in the slope within the van Krevelen space provide information on SOA functionalization (Heald et al., 2010; Van Krevelen, 1950; Ng et al., 2011). Beginning from the precursor hydrocarbon, a slope of 0 indicates alcohol group additions, a slope of -1 indicates carbonyl and alcohol additions on separate carbons or carboxylic acid additions, and a slope of -2 indicates ketone or aldehyde additions.

As seen in Fig. 3a, the laboratory-generated aerosols span a large range of $\mathrm{O}: \mathrm{C}$ and $\mathrm{H}: \mathrm{C}$ ratios. Both SOA formation condition and precursor identity influenced elemental ratios; however, precursor identity generally had a larger effect as is evident by the clusters observed for different SOA precursors. Despite these differences in chemical composition, there were no obvious trends between $\mathrm{O}: \mathrm{C}$ or $\mathrm{H}: \mathrm{C}$ and any inflammatory endpoint measured. This is similar to that observed for chemical oxidative potential as measured by DTT, where a higher $\mathrm{O}: \mathrm{C}$ did not correspond to a higher oxidative potential for both laboratory-generated and ambient aerosols (Tuet et al., 2017). This is likely due to the different formation conditions used to generate SOA, which may not be directly comparable. Nevertheless, a significant correlation $(p<0.05)$ was observed between ROS/RNS and $\overline{\mathrm{OS}}_{\mathrm{c}}$ (Fig. 3b). This positive correlation is not surprising, as a higher average oxidation state would likely correspond to a better oxidizing agent. Future studies should evaluate the effect of the degree of oxidation for SOA formed from the same SOA precursor under the same formation conditions to investigate whether atmospheric aging of aerosol (which typically leads to increases in the degree of oxidation) affects inflammatory responses. Finally, the $\mathrm{N}: \mathrm{C}$ ratio was also determined for SOA systems formed under conditions that favor the $\mathrm{RO}_{2}+\mathrm{NO}$ pathway (Fig. S4) and were found to span a large range. Similarly, there was no obvious trend between $\mathrm{N}: \mathrm{C}$ ratios and the inflammatory endpoints measured.

\subsection{Relationship between inflammatory responses}

To visualize whether there exists a relationship between inflammatory markers measured, levels of TNF- $\alpha$ and IL- 6 are shown in Fig. 4, sized by ROS/RNS. With the exception of naphthalene SOA, the inflammatory cytokine responses for all aerosol systems investigated follow an exponential curve (Fig. 4, shown in black) where there appears to be a plateau for TNF- $\alpha$ levels. Along this curve, ROS/RNS levels also appear to increase with increasing inflammatory cytokine levels to a certain point, after which ROS/RNS levels decrease. These observations are in line with the interconnected effects of both cytokines. While both TNF- $\alpha$ and IL-6 have pro-inflammatory effects that may lead to the increase of ROS/RNS production, the individual pathways are 


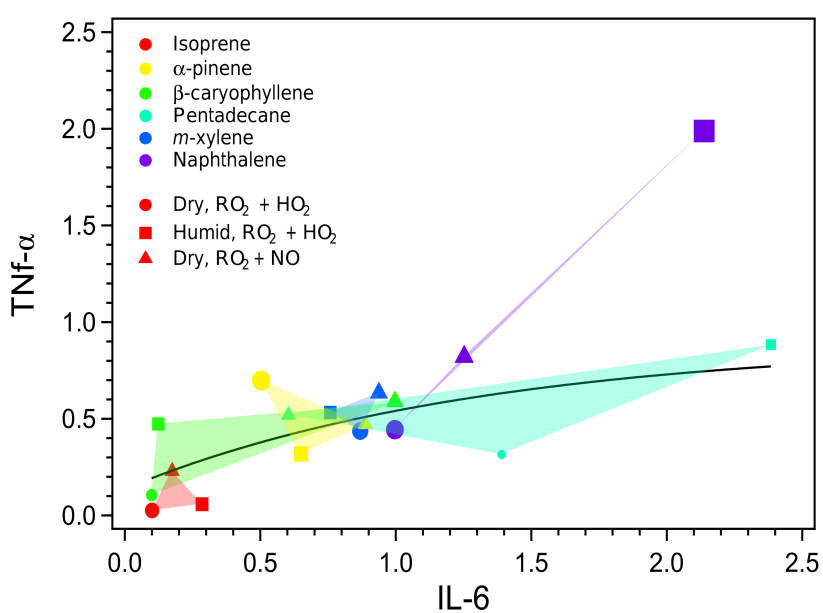

Figure 4. Area under the dose-response curve per mass of SOA for various inflammatory responses induced as a result of SOA exposure. Data points are sized according to ROS/RNS level. SOA were generated from various SOA precursors (red: isoprene, yellow: $\alpha$ pinene, green: $\beta$-caryophyllene, light blue: pentadecane, blue: $m$ xylene, and purple: naphthalene) under various conditions (circles: dry, $\mathrm{RO}_{2}+\mathrm{HO}_{2}$; squares: humid, $\mathrm{RO}_{2}+\mathrm{HO}_{2}$; and triangles: dry, $\mathrm{RO}_{2}+\mathrm{NO}$ ). A fitted curve excluding naphthalene data is shown as a guide. Shaded regions for each system, colored by SOA precursor, are also shown to show the extent of clustering and provide a visualization for the different patterns observed.

also involved in many complicated stimulation and inhibition loops and there is extensive cross talk between both pathways. For instance, TNF- $\alpha$ induces the production of glucocorticoids, which in turn inhibit both TNF- $\alpha$ and IL6 production (Wang et al., 2003). IL-6 also directly inhibits the production of TNF- $\alpha$ and other cytokines induced as a result of TNF- $\alpha$ (e.g., IL-1) and stimulates pathways that lead to the production of glucocorticoids (Kishimoto, 2003). As a result, increases in IL-6 may be accompanied by decreases in TNF- $\alpha$, resulting in the observed plateau. Furthermore, ROS/RNS levels may represent a fine balance between anti-inflammatory and pro-inflammatory effects. Both cytokines are involved in the acute-phase reaction and can affect ROS/RNS levels via pro-inflammatory pathways. IL6 also exhibits some anti-inflammatory functions and may thus lower ROS/RNS levels as well. These interconnected pathways could account for the observed parabolic pattern for ROS/RNS production. Exposure to naphthalene SOA resulted in responses outside of those observed for other aerosol systems, likely due to the formation of aromatic-ringretaining products as discussed in the previous section.

\subsection{Comparison with ambient data}

To evaluate how the oxidative potential and ROS/RNS production of the SOA systems investigated compare in the context of ambient samples, the measurements obtained in this study were plotted with those obtained in our previous study

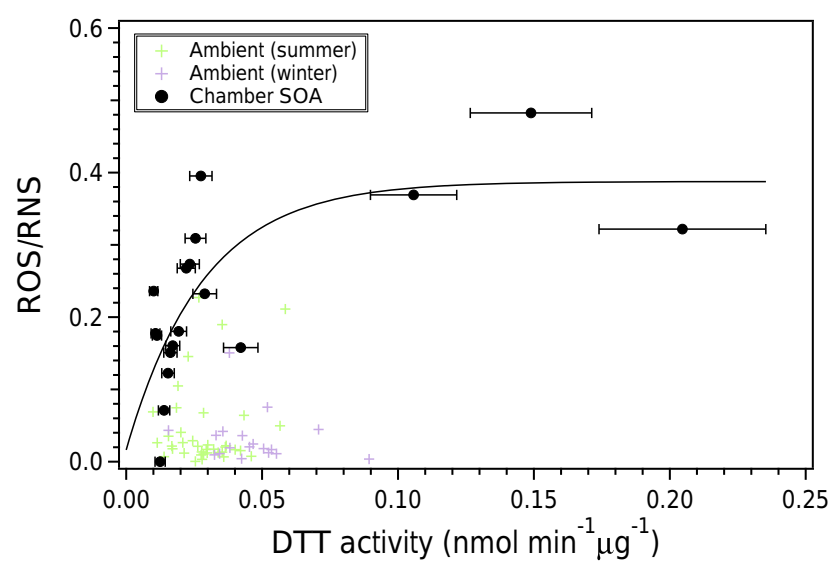

Figure 5. ROS/RNS production and intrinsic DTT activities for chamber SOA and ambient samples collected around the greater Atlanta area. All samples were analyzed using the method outlined in Cho et al. (2005) and Tuet et al. (2016). Ambient samples are colored by season as determined by solstice and equinox dates between June 2012 and October 2013 (Tuet et al., 2016). A fitted curve for laboratory-generated samples is shown as a guide.

involving ambient samples collected around the greater Atlanta area (Fig. 5; Tuet et al., 2016). These ambient samples were analyzed using the same methods for determining oxidative potential (DTT assay; Cho et al., 2005; Fang et al., 2015b) and ROS/RNS production (cellular carboxy$\mathrm{H}_{2}$ DCFDA assay; Tuet et al., 2016). Furthermore, the same extraction protocol (water-soluble extract) was followed in both studies (Tuet et al., 2016). Results from both studies are therefore directly comparable. Previously, a significant correlation between ROS/RNS production and oxidative potential as measured by DTT was observed for summer ambient samples. In the same study, correlations between ROS/RNS production and organic species were also observed for summer ambient samples, and it was suggested that these correlations may reflect contributions from photochemically produced SOA (Tuet et al., 2016).

Figure 5 shows that laboratory-generated SOA oxidative potential is comparable to that observed in ambient samples, with the exception of naphthalene SOA, which produced higher DTT activities due to its aromatic-ringretaining products (Tuet et al., 2017; Kautzman et al., 2010). Laboratory-generated SOA also induced similar or higher levels of ROS/RNS compared to ambient samples. There are many possible explanations for the observed higher response for some SOA samples. For instance, individual, single-precursor SOA systems were considered in this study, whereas ambient aerosol contains SOA from multiple precursors as well as other species that are not considered in this study (e.g., metals). Interactions between SOA from different precursors is likely to occur and may result in different response levels. Complex interactions between SOA and other species present in the ambient (e.g., metals or other 
organic species) are also likely involved (Tuet et al., 2016). Previous studies have also suggested the possibility of metalorganic complexes. For instance, Verma et al. (2012) showed that certain metals were retained on a $\mathrm{C} 18$ column, which is utilized to remove hydrophobic components, suggesting that these metals were likely complexed and removed in the process. Further chamber studies involving photochemically generated SOA and metals may elucidate these interactions. Furthermore, there are likely species present in the ambient that do not contribute to ROS/RNS production. That is, while certain species contribute to the mass of PM, there is little to no ROS/RNS production associated with these species. Ambient samples where these species comprise a significant fraction will have a low per mass ROS/RNS production level. Finally, only three SOA formation conditions were investigated in this study. There are multiple other possible oxidation mechanisms that lead to the formation of SOA in the ambient, which were not accounted for in this study. Nonetheless, despite the low ROS/RNS levels observed post SOA exposure, there is an association between ROS/RNS production and DTT activity (Fig. 5). These results suggest that our previous findings based on ambient filter samples may be extended to SOA samples. That is, while the relationship between ROS/RNS production and DTT activity is complex, DTT may serve as a useful screening tool as samples with low DTT activities are likely to produce low levels of ROS/RNS (Tuet et al., 2016).

\section{Implications}

Levels of ROS/RNS, TNF- $\alpha$, and IL-6 were measured after exposing cells to the water-soluble extract of SOA generated from the photooxidation of six SOA precursors under various formation conditions. Although previous epidemiological and ambient studies have found correlations between metals and various measures of health effects (Verma et al., 2010; Pardo et al., 2015; Burnett et al., 2001; Huang et al., 2003; Akhtar et al., 2010; Charrier and Anastasio, 2012), the measured levels of TNF- $\alpha$, IL-6, and ROS/RNS obtained in this study demonstrate that organic aerosols alone can induce a cellular response. This was previously observed for the oxidative potential as measured by DTT activity as well, where the same laboratory-generated organic aerosol samples catalyzed redox reactions and resulted in measurable DTT decay in the absence of metal species (Tuet et al., 2017).

Results from this study also show that SOA precursor identity and formation condition influenced response levels, with naphthalene SOA producing the highest cellular responses of the SOA systems investigated. As discussed previously, the aromatic functionality present in many naphthalene photooxidation products may be an important consideration for health effects. It may therefore be worthwhile to investigate other anthropogenic aromatic-ring-containing precursors as well and to closely study the cellular effects of naphthalene SOA products given its high response. Several patterns were also noted for SOA systems whose products shared similar functionalities and chemical structures. For instance, photooxidation products from pentadecane and $\beta$ caryophyllene share similarities with long chain fatty acids and may participate in membrane insertions, whereas many known products of naphthalene photooxidation are mutagens capable of inducing cellular pathways beyond those that affect the cellular redox balance (Baird et al., 2005; Helmig et al., 1992). Given these observations, it may be possible to roughly predict responses based on known SOA products as SOA systems whose products share similar functionalities and carbon chain length are likely to induce similar cellular pathways and produce similar levels of various inflammatory endpoints. Exposure studies involving individual classes of SOA products may elucidate further details as to whether these types of predictions would be plausible. Moreover, such studies could be used to determine whether the hypothesized cellular pathways are indeed involved and whether certain cellular functions are indeed affected by specific products (e.g., membrane insertion by pentadecane photooxidation products and oxidative phosphorylation decoupling by naphthalene photooxidation products).

Mixture effects may be another important consideration as ambient PM contains SOA formed from multiple SOA precursors. As a result, precursor emissions and their corresponding SOA formation potential must be considered to fully assess PM health effects. Furthermore, it may be worthwhile to investigate various prediction models for multicomponent mixtures to bridge the gap between laboratory studies and real ambient exposures. For instance, concentration addition may not apply as ambient aerosol is formed in the presence of multiple precursors and the SOA produced may induce response levels completely different from those observed for single-precursor SOA systems that comprise the mixture. Interactions between organic components and metal species have also been suggested in previous studies (Verma et al., 2012; Tuet et al., 2016) and may influence responses significantly. While these interactions were not considered in the current study, there may be evidence to support the plausibility of mixture effects as ambient PM samples produced lower levels of ROS/RNS than that of any single SOA system investigated. Laboratory chambers can serve as an ideal platform to investigate mixture effects, as experiments can be conducted under well-controlled conditions where the aerosol chemical composition and health endpoints can be determined.

Additionally, this study confirms that while there is not one simple correlation between oxidative potential and cellular responses for different PM samples, the DTT assay may serve as a useful screening tool as a low DTT activity will likely correspond to a low cellular response. Furthermore, while ROS/RNS may serve as a general indicator of oxidative stress, there may be instances where a low level of ROS/RNS does not necessary indicate a lack of cellular 
response. In the current study, ROS/RNS levels were associated with levels of inflammatory cytokines for the majority of SOA systems investigated. However, aerosol formed from the photooxidation of pentadecane induced low levels of ROS/RNS production and relatively high levels of both cytokines (i.e., higher than expected given the ROS/RNS level measured). These results suggest that at least one additional measure (e.g., inflammatory cytokines) may be required to fully interpret ROS/RNS measurements. Finally, several limitations must be considered before generalizing results from this study to in vivo exposures. For instance, only one cell type was explored in this study, whereas an organism consists of multiple tissues comprised of multiple cell types. Interactions between different cell types and tissue systems were not considered in this study. Furthermore, the doses investigated may not fully represent real world exposures due to differences in exposure routes and potential recovery from doses due to clearance. Nevertheless, this study provides perspective on the relative toxicities of different SOA systems which future studies can build upon.
Data availability. Data are available upon request to the corresponding author (ng@ chbe.gatech.edu). 
Appendix A: Abbreviations

PM particulate matter

SOA secondary organic aerosols

ROS/RNS reactive oxygen and nitrogen species

TNF- $\alpha$ tumor necrosis factor- $\alpha$

IL-6 interleukin-6 


\section{The Supplement related to this article is available online at https://doi.org/10.5194/acp-17-11423-2017- supplement.}

Competing interests. The authors declare that they have no conflict of interest.

Acknowledgements. This work was supported by the Health Effects Institute under research agreement no. 4943-RFA13-2/14-4. Wing Y. Tuet acknowledges support by the National Science Foundation Graduate Research Fellowship under grant no. DGE1650044.

Edited by: David Topping

Reviewed by: two anonymous referees

\section{References}

Akhtar, U. S., McWhinney, R. D., Rastogi, N., Abbatt, J. P., Evans, G. J., and Scott, J. A.: Cytotoxic and proinflammatory effects of ambient and source-related particulate matter (PM) in relation to the production of reactive oxygen species (ROS) and cytokine adsorption by particles, Inhal. Toxicol., 22, 37-47, 2010.

Anderson, J. O., Thundiyil, J. G., and Stolbach, A.: Clearing the Air: A Review of the Effects of Particulate Matter Air Pollution on Human Health, J. Med. Toxicol., 8, 166-175, https://doi.org/10.1007/s13181-011-0203-1, 2011.

Arashiro, M., Lin, Y.-H., Sexton, K. G., Zhang, Z., Jaspers, I., Fry, R. C., Vizuete, W. G., Gold, A., and Surratt, J. D.: In vitro exposure to isoprene-derived secondary organic aerosol by direct deposition and its effects on $C O X-2$ and $I L$ 8 gene expression, Atmos. Chem. Phys., 16, 14079-14090, https://doi.org/10.5194/acp-16-14079-2016, 2016.

Baird, W. M., Hooven, L. A., and Mahadevan, B.: Carcinogenic polycyclic aromatic hydrocarbon-DNA adducts and mechanism of action, Environ. Mol. Mutagen., 45, 106-114, https://doi.org/10.1002/em.20095, 2005.

Baltensperger, U., Dommen, J., Alfarra, R., Duplissy, J., Gaeggeler, K., Metzger, A., Facchini, M. C., Decesari, S., Finessi, E., Reinnig, C., Schott, M., Warnke, J., Hoffmann, T., Klatzer, B., Puxbaum, H., Geiser, M., Savi, M., Lang, D., Kalberer, M., and Geiser, T.: Combined determination of the chemical composition and of health effects of secondary organic aerosols: The POLYSOA project, J. Aerosol Med. Pulm. Drug Deliv., 21, 145154, https://doi.org/10.1089/jamp.2007.0655, 2008.

Baritaki, S., Apostolakis, S., Kanellou, P., Dimanche-Boitrel, M. T., Spandidos, D. A., and Bonavida, B.: Reversal of Tumor Resistance to Apoptotic Stimuli by Alteration of Membrane Fluidity: Therapeutic Implications, Adv. Cancer Res., 98, 149-190, https://doi.org/10.1016/S0065-230X(06)98005-1, 2007.

Bates, J. T., Weber, R. J., Abrams, J., Verma, V., Fang, T., Klein, M., Strickland, M. J., Sarnat, S. E., Chang, H. H., Mulholland, J. A., Tolbert, P. E., and Russell, A. G.: Reactive Oxygen Species Generation Linked to Sources of Atmospheric Particulate Mat- ter and Cardiorespiratory Effects, Environ. Sci. Technol., 49, 13605-13612, https://doi.org/10.1021/acs.est.5b02967, 2015.

Boyd, C. M., Sanchez, J., Xu, L., Eugene, A. J., Nah, T., Tuet, W. Y., Guzman, M. I., and Ng, N. L.: Secondary organic aerosol formation from the $\beta$-pinene $+\mathrm{NO}_{3}$ system: effect of humidity and peroxy radical fate, Atmos. Chem. Phys., 15, 7497-7522, https://doi.org/10.5194/acp-15-7497-2015, 2015.

Brunekreef, B. and Holgate, S. T.: Air pollution and health, Lancet, 360, 1233-1242, 2002.

Bruns, E. A., El Haddad, I., Slowik, J. G., Kilic, D., Klein, F., Baltensperger, U., and Prévôt, A. S. H.: Identification of significant precursor gases of secondary organic aerosols from residential wood combustion, Scient. Rep., 6, 27881, https://doi.org/10.1038/srep27881, 2016.

Burnett, R., Brook, J., Dann, T., Delocla, C., Philips, O., Cakmak, S., Vincent, R., Goldberg, M., and Krewski, D.: Association between particulate-and gas-phase components of urban air pollution and daily mortality in eight Canadian cities, Inhalat. Toxicol., 12, 15-39, https://doi.org/10.1080/08958370050164851, 2001.

Canagaratna, M. R., Jimenez, J. L., Kroll, J. H., Chen, Q., Kessler, S. H., Massoli, P., Hildebrandt Ruiz, L., Fortner, E., Williams, L. R., Wilson, K. R., Surratt, J. D., Donahue, N. M., Jayne, J. T., and Worsnop, D. R.: Elemental ratio measurements of organic compounds using aerosol mass spectrometry: characterization, improved calibration, and implications, Atmos. Chem. Phys., 15, 253-272, https://doi.org/10.5194/acp-15-253-2015, 2015.

Castro, L. and Freeman, B. A.: Reactive oxygen species in human health and disease, Nutrition, 17, 161-165, 2001.

Cerezo, J., Zúñiga, J., Bastida, A., Requena, A., and CerónCarrasco, J. P.: Atomistic Molecular Dynamics Simulations of the Interactions of Oleic and 2-Hydroxyoleic Acids with Phosphatidylcholine Bilayers, J. Phys. Chem. B, 115, 11727-11738, https://doi.org/10.1021/jp203498x, 2011.

Chan, A. W. H., Kautzman, K. E., Chhabra, P. S., Surratt, J. D., Chan, M. N., Crounse, J. D., Kürten, A., Wennberg, P. O., Flagan, R. C., and Seinfeld, J. H.: Secondary organic aerosol formation from photooxidation of naphthalene and alkylnaphthalenes: implications for oxidation of intermediate volatility organic compounds (IVOCs), Atmos. Chem. Phys., 9, 3049-3060, https://doi.org/10.5194/acp-9-3049-2009, 2009.

Chan, A. W. H., Chan, M. N., Surratt, J. D., Chhabra, P. S., Loza, C. L., Crounse, J. D., Yee, L. D., Flagan, R. C., Wennberg, P. O., and Seinfeld, J. H.: Role of aldehyde chemistry and $\mathrm{NO}_{x}$ concentrations in secondary organic aerosol formation, Atmos. Chem. Phys., 10, 7169-7188, https://doi.org/10.5194/acp10-7169-2010, 2010.

Chan, M. N., Surratt, J. D., Chan, A. W. H., Schilling, K., Offenberg, J. H., Lewandowski, M., Edney, E. O., Kleindienst, T. E., Jaoui, M., Edgerton, E. S., Tanner, R. L., Shaw, S. L., Zheng, M., Knipping, E. M., and Seinfeld, J. H.: Influence of aerosol acidity on the chemical composition of secondary organic aerosol from $\beta$-caryophyllene, Atmos. Chem. Phys., 11, 1735-1751, https://doi.org/10.5194/acp-11-1735-2011, 2011.

Charrier, J. G. and Anastasio, C.: On dithiothreitol (DTT) as a measure of oxidative potential for ambient particles: evidence for the importance of soluble transition metals, Atmos. Chem. Phys., 12, 9321-9333, https://doi.org/10.5194/acp-12-9321-2012, 2012. 
Chen, C. Y., Peng, W. H., Tsai, K. D., and Hsu, S. L.: Luteolin suppresses inflammation-associated gene expression by blocking NF-kappa B and AP-1 activation pathway in mouse alveolar macrophages, Life Sci., 81, 1602-1614, https://doi.org/10.1016/j.lfs.2007.09.028, 2007.

Chhabra, P. S., Flagan, R. C., and Seinfeld, J. H.: Elemental analysis of chamber organic aerosol using an aerodyne high-resolution aerosol mass spectrometer, Atmos. Chem. Phys., 10, 4111-4131, https://doi.org/10.5194/acp-10-4111-2010, 2010.

Chhabra, P. S., Ng, N. L., Canagaratna, M. R., Corrigan, A. L., Russell, L. M., Worsnop, D. R., Flagan, R. C., and Seinfeld, J. H.: Elemental composition and oxidation of chamber organic aerosol, Atmos. Chem. Phys., 11, 8827-8845, https://doi.org/10.5194/acp-11-8827-2011, 2011.

Cho, A. K., Sioutas, C., Miguel, A. H., Kumagai, Y., Schmitz, D. A., Singh, M., Eiguren-Fernandez, A., and Froines, J. R.: Redox activity of airborne particulate matter at different sites in the Los Angeles Basin, Environ. Res., 99, 40-47, https://doi.org/10.1016/j.envres.2005.01.003, 2005.

Cocker III, D. R., Mader, B. T., Kalberer, M., Flagan, R. C., and Seinfeld, J. H.: The effect of water on gas-particle partitioning of secondary organic aerosol: II. m-xylene and 1,3,5trimethylbenzene photooxidation systems, Atmos. Environ., 35, 6073-6085, https://doi.org/10.1016/S1352-2310(01)004058, 2001.

DeCarlo, P. F., Kimmel, J. R., Trimborn, A., Northway, M. J., Jayne, J. T., Aiken, A. C., Gonin, M., Fuhrer, K., Horvath, T., Docherty, K. S., Worsnop, D. R., and Jimenez, J. L.: Field-Deployable, High-Resolution, Time-ofFlight Aerosol Mass Spectrometer, Anal. Chem., 78, 8281-8289, https://doi.org/10.1021/ac061249n, 2006.

Dockery, D. W., Pope, C. A., Xu, X., Spengler, J. D., Ware, J. H., Fay, M. E., Ferris, B. G., and Speizer, F. E.: An Association between Air Pollution and Mortality in Six U.S. Cities, New Engl. J. Med., 329, 1753-1759, https://doi.org/10.1056/NEJM199312093292401, 1993.

Eddingsaas, N. C., Loza, C. L., Yee, L. D., Chan, M., Schilling, K. A., Chhabra, P. S., Seinfeld, J. H., and Wennberg, P. O.: $\alpha$-pinene photooxidation under controlled chemical conditions - Part 2: SOA yield and composition in low- and high-NO $\mathrm{NO}_{x}$ environments, Atmos. Chem. Phys., 12, 7413-7427, https://doi.org/10.5194/acp-12-7413-2012, 2012.

Edney, E. O., Driscoll, D. J., Speer, R. E., Weathers, W. S., Kleindienst, T. E., Li, W., and Smith, D. F.: Impact of aerosol liquid water on secondary organic aerosol yields of irradiated toluene/propylene/ $\mathrm{NO}_{x} /\left(\mathrm{NH}_{4}\right) 2 \mathrm{SO}_{4} /$ air mixtures, Atmos. Environ., 34, 3907-3919, https://doi.org/10.1016/S13522310(00)00174-6, 2000.

Fang, T., Guo, H., Verma, V., Peltier, R. E., and Weber, R. J.: $\mathrm{PM}_{2.5}$ water-soluble elements in the southeastern United States: automated analytical method development, spatiotemporal distributions, source apportionment, and implications for heath studies, Atmos. Chem. Phys., 15, 11667-11682, https://doi.org/10.5194/acp-15-11667-2015, 2015a.

Fang, T., Verma, V., Guo, H., King, L. E., Edgerton, E. S., and Weber, R. J.: A semi-automated system for quantifying the oxidative potential of ambient particles in aqueous extracts using the dithiothreitol (DTT) assay: results from the Southeastern Center for Air Pollution and Epidemiology (SCAPE), At- mos. Meas. Tech., 8, 471-482, https://doi.org/10.5194/amt-8471-2015, 2015b.

Gallimore, P. J., Mahon, B. M., Wragg, F. P. H., Fuller, S. J., Giorio, C., Kourtchev, I., and Kalberer, M.: Multiphase composition changes and reactive oxygen species formation during limonene oxidation in the new Cambridge Atmospheric Simulation Chamber (CASC), Atmos. Chem. Phys., 17, 9853-9868, https://doi.org/10.5194/acp-17-9853-2017, 2017.

Goldstein, A. H. and Galbally, I. E.: Known and Unexplored Organic Constituents in the Earth's Atmosphere, Environ. Sci. Technol., 41, 1514-1521, https://doi.org/10.1021/es072476p, 2007.

Guenther, A., Karl, T., Harley, P., Wiedinmyer, C., Palmer, P. I., and Geron, C.: Estimates of global terrestrial isoprene emissions using MEGAN (Model of Emissions of Gases and Aerosols from Nature), Atmos. Chem. Phys., 6, 3181-3210, https://doi.org/10.5194/acp-6-3181-2006, 2006.

Guenther, A. B., Zimmerman, P. R., Harley, P. C., Monson, R. K., and Fall, R.: Isoprene and monoterpene emission rate variability: Model evaluations and sensitivity analyses, J. Geophys. Res.Atmos., 98, 12609-12617, https://doi.org/10.1029/93JD00527, 1993.

Gurgueira, S. A., Lawrence, J., Coull, B., Murthy, G. G. K., and Gonzalez-Flecha, B.: Rapid increases in the steady-state concentration of reactive oxygen species in the lungs and heart after particulate air pollution inhalation, Environ. Health Perspect., 110, 749-755, 2002.

Haddad, J. J.: L-buthionine-(S,R)-sulfoximine, an irreversible inhibitor of gamma-glutamylcysteine synthetase, augments LPSmediated pro-inflammatory cytokine biosynthesis: evidence for the implication of an I kappa B-alpha/NF-kappa B insensitive pathway, Eur. Cytokine Netw., 12, 614-624, 2001.

Hamad, S. H., Shafer, M. M., Kadhim, A. K. H., AlOmran, S. M., and Schauer, J. J.: Seasonal trends in the composition and ROS activity of fine particulate matter in Baghdad, Iraq, Atmos. Environ., 100, 102-110, https://doi.org/10.1016/j.atmosenv.2014.10.043, 2015.

Heald, C. L., Kroll, J. H., Jimenez, J. L., Docherty, K. S., DeCarlo, P. F., Aiken, A. C., Chen, Q., Martin, S. T., Farmer, D. K., and Artaxo, P.: A simplified description of the evolution of organic aerosol composition in the atmosphere, Geophys. Res. Lett., 37, L08803, https://doi.org/10.1029/2010GL042737, 2010.

Healy, R. M., Temime, B., Kuprovskyte, K., and Wenger, J. C.: Effect of Relative Humidity on Gas/Particle Partitioning and Aerosol Mass Yield in the Photooxidation of p-Xylene, Environ. Sci. Technol., 43, 1884-1889, https://doi.org/10.1021/es802404z, 2009.

Helmig, D., Arey, J., Harger, W. P., Atkinson, R., and LopezCancio, J.: Formation of mutagenic nitrodibenzopyranones and their occurrence in ambient air, Environ. Sci. Technol., 26, 622624, https://doi.org/10.1021/es00027a028, 1992.

Henkler, F., Brinkmann, J., and Luch, A.: The Role of Oxidative Stress in Carcinogenesis Induced by Metals and Xenobiotics, Cancers, 2, 376-396, 2010.

Hensley, K., Robinson, K. A., Gabbita, S. P., Salsman, S., and Floyd, R. A.: Reactive oxygen species, cell signaling, and cell injury, Free Radical Biol. Med., 28, 1456-1462, https://doi.org/10.1016/S0891-5849(00)00252-5, 2000. 
Hoek, G., Krishnan, R. M., Beelen, R., Peters, A., Ostro, B., Brunekreef, B., and Kaufman, J. D.: Long-term air pollution exposure and cardio-respiratory mortality: a review, Environ. Health, 12, 43, https://doi.org/10.1186/1476-069X-12-43, 2013.

Hoffmann, T., Odum, J., Bowman, F., Collins, D., Klockow, D., Flagan, R., and Seinfeld, J.: Formation of Organic Aerosols from the Oxidation of Biogenic Hydrocarbons, J. Atmos. Chem., 26, 189222, https://doi.org/10.1023/A:1005734301837, 1997.

Huang, Y.-C. T., Ghio, A. J., Stonehuerner, J., McGee, J., Carter, J. D., Grambow, S. C., and Devlin, R. B.: The role of soluble components in ambient fine particles-induced changes in human lungs and blood, Inhal. Toxicol., 15, 327-342, 2003.

Jenkin, M. E., Saunders, S. M., Wagner, V., and Pilling, M. J.: Protocol for the development of the Master Chemical Mechanism, MCM v3 (Part B): tropospheric degradation of aromatic volatile organic compounds, Atmos. Chem. Phys., 3, 181-193, https://doi.org/10.5194/acp-3-181-2003, 2003.

Jia, C. and Batterman, S.: A Critical Review of Naphthalene Sources and Exposures Relevant to Indoor and Outdoor Air, Int. J. Environ. Res. Publ. Health, 7, 2903-2939, https://doi.org/10.3390/ijerph7072903, 2010.

Jimenez, J. L., Canagaratna, M. R., Donahue, N. M., Prevot, A. S. H., Zhang, Q., Kroll, J. H., DeCarlo, P. F., Allan, J. D., Coe, H., Ng, N. L., Aiken, A. C., Docherty, K. S., Ulbrich, I. M., Grieshop, A. P., Robinson, A. L., Duplissy, J., Smith, J. D., Wilson, K. R., Lanz, V. A., Hueglin, C., Sun, Y. L., Tian, J., Laaksonen, A., Raatikainen, T., Rautiainen, J., Vaattovaara, P., Ehn, M., Kulmala, M., Tomlinson, J. M., Collins, D. R., Cubison, M. J., Dunlea, J., Huffman, J. A., Onasch, T. B., Alfarra, M. R., Williams, P. I., Bower, K., Kondo, Y., Schneider, J., Drewnick, F., Borrmann, S., Weimer, S., Demerjian, K., Salcedo, D., Cottrell, L., Griffin, R., Takami, A., Miyoshi, T., Hatakeyama, S., Shimono, A., Sun, J. Y., Zhang, Y. M., Dzepina, K., Kimmel, J. R., Sueper, D., Jayne, J. T., Herndon, S. C., Trimborn, A. M., Williams, L. R., Wood, E. C., Middlebrook, A. M., Kolb, C. E., Baltensperger, U., and Worsnop, D. R.: Evolution of Organic Aerosols in the Atmosphere, Science, 326, 1525-1529, https://doi.org/10.1126/science.1180353, 2009.

Kamimura, D., Ishihara, K., and Hirano, T.: IL-6 signal transduction and its physiological roles: the signal orchestration model, in: Reviews of Physiology, Biochemistry and Pharmacology, Springer, Berlin, Heidelberg, 1-38, 2004.

Kautzman, K. E., Surratt, J. D., Chan, M. N., Chan, A. W. H., Hersey, S. P., Chhabra, P. S., Dalleska, N. F., Wennberg, P. O., Flagan, R. C., and Seinfeld, J. H.: Chemical Composition of Gas- and Aerosol-Phase Products from the Photooxidation of Naphthalene, J. Phys. Chem. A, 114, 913-934, https://doi.org/10.1021/jp908530s, 2010.

Khmelinskaia, A., Ibarguren, M., de Almeida, R. F. M., López, D. J., Paixão, V. A., Ahyayauch, H., Goñi, F. M., and Escribá, P. V.: Changes in Membrane Organization upon Spontaneous Insertion of 2-Hydroxylated Unsaturated Fatty Acids in the Lipid Bilayer, Langmuir, 30, 2117-2128, https://doi.org/10.1021/la403977f, 2014.

Kishimoto, T.: Interleukin-6, in: The Cytokine Handbook, chap. 12, 4th Edn., edited by: Thomson, A. W. and Lotze, M. T., London, 281-304, 2003.

Kleinman, M. T., Hamade, A., Meacher, D., Oldham, M., Sioutas, C., Chakrabarti, B., Stram, D., Froines, J. R., and Cho, A. K.: In- halation of concentrated ambient particulate matter near a heavily trafficked road stimulates antigen-induced airway responses in mice, J. Air Waste Manage. Assoc., 55, 1277-1288, 2005.

Kramer, A. J., Rattanavaraha, W., Zhang, Z., Gold, A., Surratt, J. D., and Lin, Y.-H.: Assessing the oxidative potential of isoprene-derived epoxides and secondary organic aerosol, Atmos. Environ., 130, 211-218, https://doi.org/10.1016/j.atmosenv.2015.10.018, 2016.

Kroll, J. H., Ng, N. L., Murphy, S. M., Flagan, R. C., and Seinfeld, J. H.: Secondary organic aerosol formation from isoprene photooxidation under high- $\mathrm{NO}_{x}$ conditions, Geophys. Res. Lett., 32, L18808, https://doi.org/10.1029/2005GL023637, 2005.

Kroll, J. H., Donahue, N. M., Jimenez, J. L., Kessler, S. H., Canagaratna, M. R., Wilson, K. R., Altieri, K. E., Mazzoleni, L. R., Wozniak, A. S., Bluhm, H., Mysak, E. R., Smith, J. D., Kolb, C. E., and Worsnop, D. R.: Carbon oxidation state as a metric for describing the chemistry of atmospheric organic aerosol, Nat. Chem., 3, 133-139, 2011.

Kumagai, Y., Koide, S., Taguchi, K., Endo, A., Nakai, Y., Yoshikawa, T., and Shimojo, N.: Oxidation of proximal protein sulfhydryls by phenanthraquinone, a component of diesel exhaust particles, Chem. Res. Toxicol., 15, 483-489, https://doi.org/10.1021/tx0100993, 2002.

Lambe, A. T., Onasch, T. B., Massoli, P., Croasdale, D. R., Wright, J. P., Ahern, A. T., Williams, L. R., Worsnop, D. R., Brune, W. H., and Davidovits, P.: Laboratory studies of the chemical composition and cloud condensation nuclei (CCN) activity of secondary organic aerosol (SOA) and oxidized primary organic aerosol (OPOA), Atmos. Chem. Phys., 11, 8913-8928, https://doi.org/10.5194/acp-11-8913-2011, 2011.

Landreman, A. P., Shafer, M. M., Hemming, J. C., Hannigan, M. P., and Schauer, J. J.: A macrophage-based method for the assessment of the reactive oxygen species (ROS) activity of atmospheric particulate matter (PM) and application to routine (daily$24 \mathrm{~h}$ ) aerosol monitoring studies, Aerosol Sci. Tech., 42, 946957, https://doi.org/10.1080/02786820802363819, 2008.

Li, N., Hao, M. Q., Phalen, R. F., Hinds, W. C., and Nel, A. E.: Particulate air pollutants and asthma - A paradigm for the role of oxidative stress in PM-induced adverse health effects, Clin. Immunol., 109, 250-265, https://doi.org/10.1016/j.clim.2003.08.006, 2003a.

Li, N., Sioutas, C., Cho, A., Schmitz, D., Misra, C., Sempf, J., Wang, M. Y., Oberley, T., Froines, J., and Nel, A.: Ultrafine particulate pollutants induce oxidative stress and mitochondrial damage, Environ. Health Perspect., 111, 455-460, https://doi.org/10.1289/ehp.6000, 2003b.

Li, N., Xia, T., and Nel, A. E.: The role of oxidative stress in ambient particulate matter-induced lung diseases and its implications in the toxicity of engineered nanoparticles, Free Rad. Biol. Med., 44, 1689-1699, https://doi.org/10.1016/j.freeradbiomed.2008.01.028, 2008.

Lim, S. S., Vos, T., Flaxman, A. D., Danaei, G., Shibuya, K., AdairRohani, H., AlMazroa, M. A., Amann, M., Anderson, H. R., Andrews, K. G., Aryee, M., Atkinson, C., Bacchus, L. J., Bahalim, A. N., Balakrishnan, K., Balmes, J., Barker-Collo, S., Baxter, A., Bell, M. L., Blore, J. D., Blyth, F., Bonner, C., Borges, G., Bourne, R., Boussinesq, M., Brauer, M., Brooks, P., Bruce, N. G., Brunekreef, B., Bryan-Hancock, C., Bucello, C., Buchbinder, R., Bull, F., Burnett, R. T., Byers, T. E., Calabria, B., Carapetis, 
J., Carnahan, E., Chafe, Z., Charlson, F., Chen, H., Chen, J. S., Cheng, A. T.-A., Child, J. C., Cohen, A., Colson, K. E., Cowie, B. C., Darby, S., Darling, S., Davis, A., Degenhardt, L., Dentener, F., Des Jarlais, D. C., Devries, K., Dherani, M., Ding, E. L., Dorsey, E. R., Driscoll, T., Edmond, K., Ali, S. E., Engell, R. E., Erwin, P. J., Fahimi, S., Falder, G., Farzadfar, F., Ferrari, A., Finucane, M. M., Flaxman, S., Fowkes, F. G. R., Freedman, G., Freeman, M. K., Gakidou, E., Ghosh, S., Giovannucci, E., Gmel, G., Graham, K., Grainger, R., Grant, B., Gunnell, D., Gutierrez, H. R., Hall, W., Hoek, H. W., Hogan, A., Hosgood III, H. D., Hoy, D., Hu, H., Hubbell, B. J., Hutchings, S. J., Ibeanusi, S. E., Jacklyn, G. L., Jasrasaria, R., Jonas, J. B., Kan, H., Kanis, J. A., Kassebaum, N., Kawakami, N., Khang, Y.-H., Khatibzadeh, S., Khoo, J.-P., Kok, C., Laden, F., Lalloo, R., Lan, Q., Lathlean, T., Leasher, J. L., Leigh, J., Li, Y., Lin, J. K., Lipshultz, S. E., London, S., Lozano, R., Lu, Y., Mak, J., Malekzadeh, R., Mallinger, L., Marcenes, W., March, L., Marks, R., Martin, R., McGale, P., McGrath, J., Mehta, S., Memish, Z. A., Mensah, G. A., Merriman, T. R., Micha, R., Michaud, C., Mishra, V., Hanafiah, K. M., Mokdad, A. A., Morawska, L., Mozaffarian, D., Murphy, T., Naghavi, M., Neal, B., Nelson, P. K., Nolla, J. M., Norman, R., Olives, C., Omer, S. B., Orchard, J., Osborne, R., Ostro, B., Page, A., Pandey, K. D., Parry, C. D. H., Passmore, E., Patra, J., Pearce, N., Pelizzari, P. M., Petzold, M., Phillips, M. R., Pope, D., Pope III, C. A., Powles, J., Rao, M., Razavi, H., Rehfuess, E. A., Rehm, J. T., Ritz, B., Rivara, F. P., Roberts, T., Robinson, C., Rodriguez-Portales, J. A., Romieu, I., Room, R., Rosenfeld, L. C., Roy, A., Rushton, L., Salomon, J. A., Sampson, U., SanchezRiera, L., Sanman, E., Sapkota, A., Seedat, S., Shi, P., Shield, K., Shivakoti, R., Singh, G. M., Sleet, D. A., Smith, E., Smith, K. R., Stapelberg, N. J. C., Steenland, K., Stöckl, H., Stovner, L. J., Straif, K., Straney, L., Thurston, G. D., Tran, J. H., Van Dingenen, R., van Donkelaar, A., Veerman, J. L., Vijayakumar, L., Weintraub, R., Weissman, M. M., White, R. A., Whiteford, H., Wiersma, S. T., Wilkinson, J. D., Williams, H. C., Williams, W., Wilson, N., Woolf, A. D., Yip, P., Zielinski, J. M., Lopez, A. D., Murray, C. J. L., and Ezzati, M.: A comparative risk assessment of burden of disease and injury attributable to 67 risk factors and risk factor clusters in 21 regions, 1990-2010: a systematic analysis for the Global Burden of Disease Study 2010, Lancet, 380, 2224-2260, https://doi.org/10.1016/S0140-6736(12)617668, 2012.

Lin, P. and Yu, J. Z.: Generation of Reactive Oxygen Species Mediated by Humic-like Substances in Atmospheric Aerosols, Environ. Sci. Technol., 45, 10362-10368, https://doi.org/10.1021/es2028229, 2011.

Lin, Y.-H., Zhang, Z., Docherty, K. S., Zhang, H., Budisulistiorini, S. H., Rubitschun, C. L., Shaw, S. L., Knipping, E. M., Edgerton, E. S., Kleindienst, T. E., Gold, A., and Surratt, J. D.: Isoprene Epoxydiols as Precursors to Secondary Organic Aerosol Formation: Acid-Catalyzed Reactive Uptake Studies with Authentic Compounds, Environ. Sci. Technol., 46, 250258, https://doi.org/10.1021/es202554c, 2012.

Lin, Y.-H., Arashiro, M., Martin, E., Chen, Y., Zhang, Z., Sexton, K. G., Gold, A., Jaspers, I., Fry, R. C., and Surratt, J. D.: Isoprene-Derived Secondary Organic Aerosol Induces the Expression of Oxidative Stress Response Genes in $\mathrm{Hu}-$ man Lung Cells, Environ. Sci. Technol. Lett., 3, 250-254, https://doi.org/10.1021/acs.estlett.6b00151, 2016.
Lin, Y.-H., Arashiro, M., Clapp, P. W., Cui, T., Sexton, K. G., Vizuete, W., Gold, A., Jaspers, I., Fry, R. C., and Surratt, J. D.: Gene Expression Profiling in $\mathrm{Hu}-$ man Lung Cells Exposed to Isoprene-Derived Secondary Organic Aerosol, Environ. Sci. Technol., 51, 8166-8175, https://doi.org/10.1021/acs.est.7b01967, 2017.

Lorentzen, R. J., Lesko, S. A., McDonald, K., and Ts'o, P. O. P.: Toxicity of Metabolic Benzo(a)pyrenediones to Cultured Cells and the Dependence upon Molecular Oxygen, Cancer Res., 39, 3194-3198, 1979.

Loza, C. L., Craven, J. S., Yee, L. D., Coggon, M. M., Schwantes, R. H., Shiraiwa, M., Zhang, X., Schilling, K. A., Ng, N. L., Canagaratna, M. R., Ziemann, P. J., Flagan, R. C., and Seinfeld, J. H.: Secondary organic aerosol yields of 12-carbon alkanes, Atmos. Chem. Phys., 14, 1423-1439, https://doi.org/10.5194/acp14-1423-2014, 2014.

Lund, A. K., Doyle-Eisele, M., Lin, Y. H., Arashiro, M., Surratt, J. D., Holmes, T., Schilling, K. A., Seinfeld, J. H., Rohr, A. C., Knipping, E. M., and McDonald, J. D.: The effects of alpha-pinene versus toluene-derived secondary organic aerosol exposure on the expression of markers associated with vascular disease, Inhal. Toxicol., 25, 309-324, https://doi.org/10.3109/08958378.2013.782080, 2013.

Matsunaga, K., Klein, T. W., Friedman, H., and Yamamoto, Y: Involvement of Nicotinic Acetylcholine Receptors in Suppression of Antimicrobial Activity and Cytokine Responses of Alveolar Macrophages to Legionella pneumophila Infection by Nicotine, J. Immunol., 167, 6518-6524, https://doi.org/10.4049/jimmunol.167.11.6518, 2001.

Mbawuike, I. N. and Herscowitz, H. B.: MH-S, a murine alveolar macrophage cell line: morphological, cytochemical, and functional characteristics, J. Leukocyte Biol., 46, 119-127, 1989.

McDonald, J. D., Doyle-Eisele, M., Campen, M. J., Seagrave, J., Holmes, T., Lund, A., Surratt, J. D., Seinfeld, J. H., Rohr, A. C., and Knipping, E. M.: Cardiopulmonary response to inhalation of biogenic secondary organic aerosol, Inhal. Toxicol., 22, 253265, https://doi.org/10.3109/08958370903148114, 2010.

McDonald, J. D., Doyle-Eisele, M., Kracko, D., Lund, A., Surratt, J. D., Hersey, S. P., Seinfeld, J. H., Rohr, A. C., and Knipping, E. M.: Cardiopulmonary response to inhalation of secondary organic aerosol derived from gasphase oxidation of toluene, Inhal. Toxicol., 24, 689-697, https://doi.org/10.3109/08958378.2012.712164, 2012.

McWhinney, R. D., Zhou, S., and Abbatt, J. P. D.: Naphthalene SOA: redox activity and naphthoquinone gasparticle partitioning, Atmos. Chem. Phys., 13, 9731-9744, https://doi.org/10.5194/acp-13-9731-2013, 2013.

Mohr, C., Huffman, J. A., Cubison, M. J., Aiken, A. C., Docherty, K. S., Kimmel, J. R., Ulbrich, I. M., Hannigan, M., and Jimenez, J. L.: Characterization of Primary Organic Aerosol Emissions from Meat Cooking, Trash Burning, and Motor Vehicles with High-Resolution Aerosol Mass Spectrometry and Comparison with Ambient and Chamber Observations, Environ. Sci. Technol., 43, 2443-2449, https://doi.org/10.1021/es8011518, 2009.

Ng, N. L., Chhabra, P. S., Chan, A. W. H., Surratt, J. D., Kroll, J. H., Kwan, A. J., McCabe, D. C., Wennberg, P. O., Sorooshian, A., Murphy, S. M., Dalleska, N. F., Flagan, R. C., and Seinfeld, J. H.: Effect of $\mathrm{NO}_{x}$ level on secondary organic aerosol (SOA) forma- 
tion from the photooxidation of terpenes, Atmos. Chem. Phys., 7, 5159-5174, https://doi.org/10.5194/acp-7-5159-2007, 2007a. Ng, N. L., Kroll, J. H., Chan, A. W. H., Chhabra, P. S., Flagan, R. C., and Seinfeld, J. H.: Secondary organic aerosol formation from m-xylene, toluene, and benzene, Atmos. Chem. Phys., 7, 3909-3922, https://doi.org/10.5194/acp-7-3909-2007, 2007b.

Ng, N. L., Canagaratna, M. R., Zhang, Q., Jimenez, J. L., Tian, J., Ulbrich, I. M., Kroll, J. H., Docherty, K. S., Chhabra, P. S., Bahreini, R., Murphy, S. M., Seinfeld, J. H., Hildebrandt, L., Donahue, N. M., DeCarlo, P. F., Lanz, V. A., Prévôt, A. S. H., Dinar, E., Rudich, Y., and Worsnop, D. R.: Organic aerosol components observed in Northern Hemispheric datasets from Aerosol Mass Spectrometry, Atmos. Chem. Phys., 10, 46254641, https://doi.org/10.5194/acp-10-4625-2010, 2010.

Ng, N. L., Canagaratna, M. R., Jimenez, J. L., Chhabra, P. S., Seinfeld, J. H., and Worsnop, D. R.: Changes in organic aerosol composition with aging inferred from aerosol mass spectra, Atmos. Chem. Phys., 11, 6465-6474, https://doi.org/10.5194/acp11-6465-2011, 2011.

Nguyen, T. B., Roach, P. J., Laskin, J., Laskin, A., and Nizkorodov, S. A.: Effect of humidity on the composition of isoprene photooxidation secondary organic aerosol, Atmos. Chem. Phys., 11, 6931-6944, https://doi.org/10.5194/acp-11-6931-2011, 2011.

Oberdörster, G.: Lung Dosimetry: Pulmonary Clearance of Inhaled Particles, Aerosol Sci. Tech., 18, 279-289, https://doi.org/10.1080/02786829308959605, 1993.

Oberdörster, G., Ferin, J., Gelein, R., Soderholm, S. C., and Finkelstein, J.: Role of the alveolar macrophage in lung injury: studies with ultrafine particles, Environ. Health Perspect., 97, 193-199, 1992.

Pan, Q. and Shimizu, I.: Imputation Variance Estimation by Multiple Imputation Method for the National Hospital Discharge Survey, Section on Survey Research Methods, JSM 2009, 11061114, 2009.

Pardo, M., Shafer, M. M., Rudich, A., Schauer, J. J., and Rudich, Y.: Single Exposure to near Roadway Particulate Matter Leads to Confined Inflammatory and Defense Responses: Possible Role of Metals, Environ. Sci. Technol., 49, 8777-8785, https://doi.org/10.1021/acs.est.5b01449, 2015.

Philip, M., Rowley, D. A., and Schreiber, H.: Inflammation as a tumor promoter in cancer induction, Seminars Cancer Biol., 14, 433-439, https://doi.org/10.1016/j.semcancer.2004.06.006, 2004.

Piccot, S. D., Watson, J. J., and Jones, J. W.: A global inventory of volatile organic compound emissions from anthropogenic sources, J. Geophys. Res.-Atmos., 97, 9897-9912, https://doi.org/10.1029/92JD00682, 1992.

Platt, S. M., Haddad, I. E., Pieber, S. M., Huang, R. J., Zardini, A. A., Clairotte, M., Suarez-Bertoa, R., Barmet, P., Pfaffenberger, L., Wolf, R., Slowik, J. G., Fuller, S. J., Kalberer, M., Chirico, R., Dommen, J., Astorga, C., Zimmermann, R., Marchand, N., Hellebust, S., Temime-Roussel, B., Baltensperger, U., and Prévôt, A. S. H.: Two-stroke scooters are a dominant source of air pollution in many cities, Nat. Commun., 5, 3749, https://doi.org/10.1038/ncomms4749, 2014.

Pope, C. A., Burnett, R. T., Thun, M. J., Calle, E. E., Krewski, D., Ito, K., and Thurston, G. D.: Lung cancer, cardiopulmonary mortality, and long-term exposure to fine particu- late air pollution, J. Am. Med. Assoc., 287, 1132-1141, https://doi.org/10.1001/jama.287.9.1132, 2002.

Pope III, C. A. and Dockery, D. W.: Health effects of fine particulate air pollution: Lines that connect, J. Air Waste Manage. Assoc., 56, 709-742, 2006.

Rattanavaraha, W., Rosen, E., Zhang, H., Li, Q., Pantong, K., and Kamens, R. M.: The reactive oxidant potential of different types of aged atmospheric particles: An outdoor chamber study, Atmos. Environ., 45, 3848-3855, https://doi.org/10.1016/j.atmosenv.2011.04.002, 2011.

Robinson, A. L., Donahue, N. M., Shrivastava, M. K., Weitkamp, E. A., Sage, A. M., Grieshop, A. P., Lane, T. E., Pierce, J. R., and Pandis, S. N.: Rethinking Organic Aerosols: Semivolatile Emissions and Photochemical Aging, Science, 315, 1259-1262, https://doi.org/10.1126/science.1133061, 2007.

Rogge, W. F., Hildemann, L. M., Mazurek, M. A., Cass, G. R., and Simoneit, B. R. T.: Sources of fine organic aerosol. 1. Charbroilers and meat cooking operations, Environ. Sci. Technol., 25, 1112-1125, https://doi.org/10.1021/es00018a015, 1991.

Saffari, A., Hasheminassab, S., Wang, D., Shafer, M. M., Schauer, J. J., and Sioutas, C.: Impact of primary and secondary organic sources on the oxidative potential of quasiultrafine particles $\left(\mathrm{PM}_{0.25}\right)$ at three contrasting locations in the Los Angeles Basin, Atmos. Environ., 120, 286-296, https://doi.org/10.1016/j.atmosenv.2015.09.022, 2015.

Sankaran, K. and Herscowitz, H. B.: Phenotypic and functional heterogeneity of the murine alveolar macrophage-derived cell line MH-S, J. Leukocyte Biol., 57, 562-568, 1995.

Spector, A. A. and Yorek, M. A.: Membrane lipid composition and cellular function, J. Lipid Res., 26, 1015-1035, 1985.

Stirnweis, L., Marcolli, C., Dommen, J., Barmet, P., Frege, C., Platt, S. M., Bruns, E. A., Krapf, M., Slowik, J. G., Wolf, R., Prévôt, A. S. H., El-Haddad, I., and Baltensperger, U.: $\alpha$-Pinene secondary organic aerosol yields increase at higher relative humidity and low NOx conditions, Atmos. Chem. Phys. Discuss., https://doi.org/10.5194/acp-2016-717, in review, 2016.

Surratt, J. D., Chan, A. W. H., Eddingsaas, N. C., Chan, M., Loza, C. L., Kwan, A. J., Hersey, S. P., Flagan, R. C., Wennberg, P. O., and Seinfeld, J. H.: Reactive intermediates revealed in secondary organic aerosol formation from isoprene, P. Natl. Acad. Sci. USA, 107, 6640-6645, https://doi.org/10.1073/pnas.0911114107, 2010.

Tao, F., Gonzalez-Flecha, B., and Kobzik, L.: Reactive oxygen species in pulmonary inflammation by ambient particulates, Free Rad. Biol. Med., 35, 327-340, https://doi.org/10.1016/S08915849(03)00280-6, 2003.

Tasoglou, A. and Pandis, S. N.: Formation and chemical aging of secondary organic aerosol during the $\beta$ caryophyllene oxidation, Atmos. Chem. Phys., 15, 6035-6046, https://doi.org/10.5194/acp-15-6035-2015, 2015.

Terada, H.: Uncouplers of oxidative phosphorylation, Environ. Health Perspect., 87, 213-218, 1990.

Tuet, W. Y., Fok, S., Verma, V., Tagle Rodriguez, M. S., Grosberg, A., Champion, J. A., and Ng, N. L.: Dose-dependent intracellular reactive oxygen and nitrogen species (ROS/RNS) production from particulate matter exposure: comparison to oxidative potential and chemical composition, Atmos. Environ., 144, 335-344, https://doi.org/10.1016/j.atmosenv.2016.09.005, 2016. 
Tuet, W. Y., Chen, Y., Xu, L., Fok, S., Gao, D., Weber, R. J., and $\mathrm{Ng}$, N. L.: Chemical oxidative potential of secondary organic aerosol (SOA) generated from the photooxidation of biogenic and anthropogenic volatile organic compounds, Atmos. Chem. Phys., 17, 839-853, https://doi.org/10.5194/acp-17-8392017, 2017.

Van Krevelen, D.: Graphical-statistical method for the study of structure and reaction processes of coal, Fuel, 29, 269-284, 1950.

Verma, V., Shafer, M. M., Schauer, J. J., and Sioutas, C.: Contribution of transition metals in the reactive oxygen species activity of PM emissions from retrofitted heavy-duty vehicles, Atmos. Environ., 44, 5165-5173, https://doi.org/10.1016/j.atmosenv.2010.08.052, 2010.

Verma, V., Rico-Martinez, R., Kotra, N., King, L., Liu, J. M., Snell, T. W., and Weber, R. J.: Contribution of Water-Soluble and Insoluble Components and Their Hydrophobic/Hydrophilic Subfractions to the Reactive Oxygen Species-Generating Potential of Fine Ambient Aerosols, Environ. Sci. Technol., 46, 1138411392, https://doi.org/10.1021/es302484r, 2012.

Verma, V., Fang, T., Xu, L., Peltier, R. E., Russell, A. G., Ng, N. L., and Weber, R. J.: Organic Aerosols Associated with the Generation of Reactive Oxygen Species (ROS) by Water-Soluble $\mathrm{PM}_{2.5}$, Environ. Sci. Technol., 49, 4646-4656, https://doi.org/10.1021/es505577w, 2015a.

Verma, V., Wang, Y., El-Afifi, R., Fang, T., Rowland, J., Russell, A. G., and Weber, R. J.: Fractionating ambient humic-like substances (HULIS) for their reactive oxygen species activity - Assessing the importance of quinones and atmospheric aging, Atmos. Environ., 120, 351-359, https://doi.org/10.1016/j.atmosenv.2015.09.010, 2015b.

Vivanco, M. G. and Santiago, M.: Secondary Organic Aerosol Formation from the Oxidation of a Mixture of Organic Gases in a Chamber, in: Air Quality, edited by: Kumar, A., InTech, https://doi.org/10.5772/9761, 2010.

Wang, H., Czura, C., and Tracey, K.: Tumor necrosis factor, in: The Cytokine Handbook, chap. 35, 4th Edn., edited by: Thomson, A. W. and Lotze, M. T., London, 837-860, 2003.

Wen, Y., Gu, J., Chakrabarti, S. K., Aylor, K., Marshall, J., Takahashi, Y., Yoshimoto, T., and Nadler, J. L.: The Role of 12/15Lipoxygenase in the Expression of Interleukin-6 and Tumor Necrosis Factor- $\alpha$ in Macrophages, Endocrinology, 148, 13131322, https://doi.org/10.1210/en.2006-0665, 2007.
Wiseman, H. and Halliwell, B.: Damage to DNA by reactive oxygen and nitrogen species: role in inflammatory disease and progression to cancer, Biochem. J., 313, 17-29, 1996.

Witkamp, R. and Monshouwer, M.: Signal transduction in inflammatory processes, current and future therapeutic targets: A mini review, Veterin. Quart., 22, 11-16, https://doi.org/10.1080/01652176.2000.9695016, 2000.

Wong, J. P. S., Lee, A. K. Y., and Abbatt, J. P. D.: Impacts of Sulfate Seed Acidity and Water Content on Isoprene Secondary Organic Aerosol Formation, Environ. Sci. Technol., 49, 13215-13221, https://doi.org/10.1021/acs.est.5b02686, 2015.

Xu, L., Kollman, M. S., Song, C., Shilling, J. E., and Ng, N. L.: Effects of $\mathrm{NO}_{x}$ on the Volatility of Secondary Organic Aerosol from Isoprene Photooxidation, Environ. Sci. Technol., 48, 22532262, https://doi.org/10.1021/es404842g, 2014.

Xu, L., Guo, H., Boyd, C. M., Klein, M., Bougiatioti, A., Cerully, K. M., Hite, J. R., Isaacman-VanWertz, G., Kreisberg, N. M., Knote, C., Olson, K., Koss, A., Goldstein, A. H., Hering, S. V., de Gouw, J., Baumann, K., Lee, S.-H., Nenes, A., Weber, R. J., and $\mathrm{Ng}, \mathrm{N}$. L.: Effects of anthropogenic emissions on aerosol formation from isoprene and monoterpenes in the southeastern United States, P. Natl. Acad. Sci. USA, 112, 37-42, https://doi.org/10.1073/pnas.1417609112, 2015.

Zhang, Q., Jimenez, J. L., Canagaratna, M. R., Allan, J. D., Coe, H., Ulbrich, I., Alfarra, M. R., Takami, A., Middlebrook, A. M., Sun, Y. L., Dzepina, K., Dunlea, E., Docherty, K., DeCarlo, P. F., Salcedo, D., Onasch, T., Jayne, J. T., Miyoshi, T., Shimono, A., Hatakeyama, S., Takegawa, N., Kondo, Y., Schneider, J., Drewnick, F., Borrmann, S., Weimer, S., Demerjian, K., Williams, P., Bower, K., Bahreini, R., Cottrell, L., Griffin, R. J., Rautiainen, J., Sun, J. Y., Zhang, Y. M., and Worsnop, D. R.: Ubiquity and dominance of oxygenated species in organic aerosols in anthropogenically-influenced Northern Hemisphere midlatitudes, Geophys. Res. Lett., 34, L13801, https://doi.org/10.1029/2007GL029979, 2007. 